University of Wollongong

Research Online

Faculty of Science, Medicine and Health -

Papers: part A

Faculty of Science, Medicine and Health

$1-1-2013$

\title{
Middle Carboniferous-Early Triassic eclogite-blueschist blocks within a serpentinite mélange at Port Macquarie, eastern Australia: implications for the evolution of Gondwana's eastern margin
}

\author{
Allen P. Nutman \\ University of Wollongong, anutman@uow.edu.au \\ Solomon Buckman \\ University of Wollongong, solomon@uow.edu.au \\ Hiroshi Hidaka \\ University of Hiroshima \\ Tomoyuki Kamiichi \\ University of Hiroshima \\ Elena Belousova \\ Macquarie University \\ See next page for additional authors \\ Follow this and additional works at: https://ro.uow.edu.au/smhpapers \\ Part of the Medicine and Health Sciences Commons, and the Social and Behavioral Sciences \\ Commons
}

\section{Recommended Citation}

Nutman, Allen P.; Buckman, Solomon; Hidaka, Hiroshi; Kamiichi, Tomoyuki; Belousova, Elena; and Aitchison, Jonathan, "Middle Carboniferous-Early Triassic eclogite-blueschist blocks within a serpentinite mélange at Port Macquarie, eastern Australia: implications for the evolution of Gondwana's eastern margin" (2013). Faculty of Science, Medicine and Health - Papers: part A. 1240.

https://ro.uow.edu.au/smhpapers/1240

Research Online is the open access institutional repository for the University of Wollongong. For further information contact the UOW Library: research-pubs@uow.edu.au 


\title{
Middle Carboniferous-Early Triassic eclogite-blueschist blocks within a serpentinite mélange at Port Macquarie, eastern Australia: implications for the evolution of Gondwana's eastern margin
}

\begin{abstract}
The New England Orogen of easternmost Australia is dominated by suites of Palaeozoic to earliest Mesozoic rocks that formed in supra-subduction zone settings at Gondwana's eastern margin. On the northern New South Wales coast at Rocky Beach, Port Macquarie, a serpentinite mélange carries rare tectonic blocks of low-grade, high-pressure, metamorphic rocks derived from sedimentary and igneous protoliths. Dominant assemblages are glaucophane. + . phengite. \pm . garnet. \pm . lawsonite. \pm . calcite. \pm . albite blueschists and lawsonite-bearing retrogressed garnet. +. omphacite eclogites. In some blocks with sedimentary protoliths, eclogite forms folded layers within the blueschists, which is interpreted as $\mathrm{Mn} /(\mathrm{Mn} .+$. Fe) compositional control on the development of blueschist versus eclogite assemblages. Review of previous studies indicates pressure-temperature conditions of $0.7-0.5$. GPa and $\leq .450 .{ }^{\circ} \mathrm{C}$. Three samples of high-pressure metasedimentary rocks contain Archaean to 251. \pm . 6. Ma (PermoTriassic) zircons, with the majority of the grains being Middle Devonian to Middle Carboniferous in age (380-340. Ma). Regardless of age, all grains show pitting and variable rounding of their exteriors. This morphology is attributed to abrasion in sedimentary systems, suggesting that they are all detrital grains. New in situ metamorphic zircon growth did not develop because of the low temperature $\left(\leq .450 .{ }^{\circ} \mathrm{C}\right)$ of metamorphism. The Permo-Triassic, Devonian and Carboniferous zircons show strong heavy rare earth element enrichment and negative europium anomalies, indicating that they grew in low pressure igneous systems, not in a garnet-rich plagioclase-absent high pressure metamorphic environment. Therefore the youngest of these detrital zircons provides the maximum age of the metamorphism. A titanite. +. rutile porphyroblast within an eclogite has a U-Pb age of 332. \pm . 140. Ma (poor precision due to very low $U$ abundances of mostly
\end{abstract}

\section{Keywords}

blueschist, blocks, within, serpentinite, $m$, lange, port, macquarie, eastern, eclogite, australia, middle, implications, evolution, gondwana, 039, margin, triassic, early, carboniferous, GeoQuest

\section{Disciplines}

Medicine and Health Sciences | Social and Behavioral Sciences

\section{Authors}

Allen P. Nutman, Solomon Buckman, Hiroshi Hidaka, Tomoyuki Kamiichi, Elena Belousova, and Jonathan Aitchison 
1 Gondwana Research DOI: 10.1016/j.gr.2013.01.009

2 Middle Carboniferous - Early Triassic eclogite-blueschist blocks within a

3 serpentinite mélange at Port Macquarie, eastern Australia: Implications for

$9{ }^{1}$ School of Earth \& Environmental Sciences, University of Wollongong, Wollongong, NSW 2522, Australia

$11{ }^{2}$ Department of Earth and Planetary Systems Sciences, University of Hiroshima, 1-3-1 Kagamiyama, Higashi-Hiroshima 739-8526, Japan 


\section{Abstract}

18 The New England Orogen of easternmost Australia is dominated by suites of Palaeozoic to

19 earliest Mesozoic rocks that formed in supra-subduction zone settings at Gondwana's eastern

20 margin. On the northern New South Wales coast at Rocky Beach, Port Macquarie, a

21 serpentinite mélange carries rare tectonic blocks of low-grade, high-pressure, metamorphic

22 rocks derived from sedimentary and igneous protoliths. Dominant assemblages are

23 glaucophane + phengite \pm garnet \pm lawsonite \pm calcite \pm albite blueschists and

24 lawsonite-bearing retrogressed garnet + omphacite eclogites. In some blocks with sedimentary

25 protoliths, eclogite forms folded layers within the blueschists, which is interpreted as

$26 \mathrm{Mn} /(\mathrm{Mn}+\mathrm{Fe})$ compositional control on the development of blueschist versus eclogite

27 assemblages. Review of previous studies indicates pressure-temperature conditions of 0.7-0.5

$28 \mathrm{GPa}$ and $\leq 450^{\circ} \mathrm{C}$. Three samples of high-pressure metasedimentary rocks contain Archaean to

$29251 \pm 6 \mathrm{Ma}$ (Permo-Triassic) zircons, with the majority of the grains being Middle Devonian to

30 Middle Carboniferous in age (380-340 Ma). Regardless of age, all grains show pitting and

31 variable rounding of their exteriors. This morphology is attributed to abrasion in sedimentary

32 systems, suggesting that they are all detrital grains. New in situ metamorphic zircon growth did

33 not develop because of the low temperature $\left(\leq 450^{\circ} \mathrm{C}\right)$ of metamorphism. The Permo-Triassic,

34 Devonian and Carboniferous zircons show strong heavy rare earth element enrichment and

35 negative europium anomalies, indicating that they grew in low pressure igneous systems, not in

36 a garnet-rich plagioclase-absent high pressure metamorphic environment. Therefore the

37 youngest of these detrital zircons provide the maximum age of the metamorphism. A titanite +

38 rutile porphyroblast within an eclogite has a $\mathrm{U}-\mathrm{Pb}$ age of $332 \pm 140 \mathrm{Ma}$ (poor precision due to

39 very low $U$ abundances of mostly $<1 \mathrm{ppm}$.) and provides an imprecise direct age for

40 metamorphism. In the south of the Port Macquarie area, the Lorne Basin $\geq 220$ Ma Triassic

41 sedimentary and volcanic rocks unconformably overlie serpentinite mélange, and provide the

42 minimum age of the high-pressure metamorphism. Our preferred interpretation is that the 251 
43 Ma zircons are detrital and thus the Port Macquarie high-pressure metamorphism is

44 constrained to the end of the Permian - Early Triassic. Emplacement of the serpentinite

45 mélange carrying the Rocky Beach high-pressure rocks might have been due to docking of a

46 Permian oceanic island arc (represented by the Gympie terrane in southern Queensland?) and

47 an Andean-style arc at the eastern Australian margin (expressed in the New England Orogen by

48 260-230 Ma north-south orientated magmatic belts). Alternatively, if the $251 \mathrm{Ma}$ grains are

49 regarded as having grown in thin pegmatites, then the dominant Devonian-Carboniferous

50 detrital population still indicate a maximum age for the high pressure metamorphism of ca. 340

51 Ma. A $\leq 340$ Ma age of metamorphism would still be much younger than the previously

52 suggested ca. $470 \mathrm{Ma}$ (Ordovician) age, which was based on Ar-Ar dating of phengites.

53

54 Keywords: New England Orogen; Blueschist-eclogite; Serpentinites; Gondwana; Port

55 Macquarie 


\section{Introduction}

Throughout the Palaeozoic, eastern Australia was at the margin of Gondwana, and was growing eastwards via the addition of granitoids and their volcanic and sedimentary carapaces, largely formed in supra-subduction zone settings (e.g., Aitchison et al., 1994, Cawood, 2005; Glen, 2005; Cawood et al., 2011; Rosenbaum et al., 2012). Lineaments carrying slivers of tectonised, serpentinised, mantle are found intertwined between the granitoids and their carapaces (e.g., Spaggiari et al., 2004; Glen; 2005). The serpentinites carry sedimentary and igneous rocks as mélanges of exotic blocks, including rare ones carrying eclogite and blueschist facies assemblages. They are interpreted as vestiges of subduction zone assemblages modified by younger tectonic events (e.g., Glen, 2005).

In the New England Orogen (NEO) of northeastern New South Wales and south-eastern Queensland (Fig. 1), two notable occurrences of serpentinite mélange are the Great Serpentine Belt in the Peel-Manning fault system in the southwest (Benson, 1913, 1914a, b, 1915a,b; Offler and Williams, 1987; Sano et al., 2004; Phillips and Offler, 2011) and ate Port Macquarie in the southeast (Benson, 1918; Barron et al., 1976; Leitch, 1980; Och et al., 2003, 2007; Lennox and Offler, 2009). Exotic blocks within the Great Serpentine Belt have so far all yielded latest Neoproterozoic to early Palaeozoic U-Pb zircon protolith ages (Aitchison and Ireland, 1995; Watanabe et al., 1997). The NEO serpentinites have been interpreted as exhumed vestiges of early Palaeozoic subduction zone complexes, caught-up in latest Palaeozoic to earliest Mesozoic crust-forming events (e.g., Och et al., 2003). However, the protolith ages of the included blocks in the serpentinites can give only maximum, rather than direct, ages for the high-pressure metamorphic events and the incorporation of the blocks within the serpentinite belts. Age determinations on minerals grown or recrystallised during high-pressure metamorphism will give the sought-after direct 
83 metamorphic ages. Particularly at medium to high metamorphic grade, this can be

84 achieved by employing $\mathrm{U}-\mathrm{Pb}$ dating of metamorphic zircon growths or $\mathrm{Sm}-\mathrm{Nd}$

85 determinations on coexisting garnet and omphacite (e.g., Hermann et al., 2001; Gilotti

86 et al., 2004; Nutman et al., 2008). At low grade, direct determination of metamorphic

87 ages of high pressure assemblages becomes difficult, because under these low

88 temperature conditions the growth of metamorphic zircon is uncommon and because

89 of the issue of excess Ar in metamorphic phengites derived from older detrital grains

90 resulting in incorrect, older ages in K-Ar and Ar-Ar geochronology (e.g., Arnauld and

91 Kelley, 1995; Li et al., 1999; Sherlock and Kelley, 2002).

92 In this paper we present field relationships, zircon U-Pb geochronology and

93 rare earth element (REE) chemistry and metamorphic rutile and titanite $\mathrm{U}-\mathrm{Pb}$ dating

94 from metasedimentary blueschist and eclogite facies blocks in the NEO's easternmost

95 serpentinite mélange at Port Macquarie (Fig. 1). Our results show that these rocks

96 formed at the end of the Palaeozoic and that high-pressure metamorphism was most

97 likely at $\leq 251 \mathrm{Ma}$, i.e., ca. 200 million years later than the previously proposed

98 Ordovician timing for this event at Port Macquarie (Fukui et al., 1995; Och et al., 2003,

99 2007). We discuss the implications of this Permo-Triassic event for the evolution of

100 Gondwana's eastern margin.

101

102 2. Regional geological setting - the New England Orogen

103 The New England Orogen (NEO; Fig. 1) is the easternmost, youngest,

104 component of the Tasmanides orogenic belt of eastern Australia (Flood and Aitchison,

105 1988; Harrington and Korsch, 1985; Leitch, 1974, 1975; Murray et al., 1987;

106 Aitchison et al., 1994; Cawood, 2005; Glen, 2005; Cawood et al., 2011; Rosenbaum,

107 2012). The NEO contains latest Neoproterozoic to Permo-Triassic arc-related 
108 magmatic rocks (Leitch, 1974; Murray et al., 1987; Aitchison et al., 1994; Cawood et

109 al., 2011; Rosenbaum et al., 2012). Devonian-Carboniferous supra-subduction zone

110 components are the Tamworth Belt forearc basin and Tablelands Complex

111 accretionary wedge rocks (Fig. 1) which developed on top of previously-accreted early

112 Palaeozoic oceanic terranes (Flood and Aitchison, 1988). The core of a

113 Devonian-Carboniferous volcanic arc lies farther to the west, but it is now largely

114 obscured by post-Devonian sedimentary rocks (Leitch, 1974, 1975; McPhie and

115 Fergusson, 1987; Roberts and Engel, 1987; Roberts and James, 2010; Roberts et al., $1161995,2004,2006)$. It is only evident from intermediate to felsic volcanic rocks of the

117 Currabubula Arc on the western edge of the Tamworth Belt. Southwards,

118 tectonically-displaced forearc basin rocks in the Hastings Block (Figure 1 inset) are

119 correlated with the Tamworth Belt. The Tablelands Complex rocks are mostly

120 Carboniferous to early Permian deep marine volcaniclastic turbidites and cherts, mafic

121 volcanic rocks and olistostromal deposits (Leitch \& Cawood, 1980; Cawood, 1982;

122 Fergusson, 1984; Aitchison et al., 1994). These rocks show penetrative steeply dipping

123 fabrics and display prehnite-pumpellyite/lower greenschist to amphibolite-facies

124 metamorphic assemblages (Binns et al., 1966; Korsch and Harrington, 1981; Dirks et

125 al., 1992). The Peel-Manning fault system (Fig. 1a) forms the tectonic boundary

126 between the Tamworth Belt and the Tablelands Complex. It is marked by serpentinite

127 belts that contain exotic tectonic blocks of early Phanerozoic to Neoproterozoic

128 arc-related rocks and rare blocks of eclogite and blueschist facies rocks (e.g., Shaw and

129 Flood, 1974; Fukui et al., 1995; Aitchison and Ireland, 1995). Generally, an early

130 Palaeozoic age has been ascribed for the Peel-Manning fault system assemblage and

131 the age of high-pressure metamorphic blocks within it (e.g., Fukui et al., 1995; Phillips

132 and Offler, 2011), albeit it is recognised that the Peel-Manning serpentinites were 
133 deformed and metamorphosed at the end of the Permian (Aitchison and Flood, 1992;

134 Aitchison et al., 1997).

135 The Early Permian history of the NEO is marked by development of

136 sedimentary basins dominated by proximal seep marine mass flow deposits (Aitchison

137 and Flood, 1992; Aitchison et al., 1997; Korsch et al., 2009). The Early Permian

138 granitoids are the S-type Bundarra granite and the Hillgrove suite, and several other

139 small S- and I-type plutons; Figure 1a). U-Pb zircon ages (Cawood et al., 2011;

140 Rosenbaum et al., 2012) show that these were all emplaced between 296 and 267 Ma.

141 Thereafter, from 250 to $225 \mathrm{Ma}$, subduction resumed, and there was the emplacement

142 of eastward-stepping north-south trending arc-related plutons. The 250-225 Ma

143 magmatism produced I-type granitoids and calc-alkaline volcanic rocks, which are

144 interpreted to have been emplaced in an Andean arc setting (Cawood, 1984; Flood \&

145 Shaw, 1975; Bryant et al., 1997).

146 One proposed geodynamic setting for 296-230 Ma crustal evolution is an

147 eastwards, asymmetric, subduction rollback, that between ca. 300 and $267 \mathrm{Ma}$ lead to

148 the evolution of an orocline in the southern end of the NEO (Jenkins et al., 2002;

149 Collins and Richards, 2008; Cawood et al., 2011; Rosenbaum et al., 2012). After 267

150 Ma the proposed orocline in the southern NEO continued to tighten (Murray et al.,

151 1987; Cawood et al., 2011; Rosenbaum et al., 2012) and hence there was a hiatus in arc

152 magmatism between 267-250 Ma. Subduction with arc magmatism resumed from 250

153 Ma. Thereafter, there was the onset of the Hunter-Bowen orogeny - a phase of E-W

154 contractional deformation (Collins, 1991; Holcombe et al., 1997; Korsch et al., 2009).

155 This orogeny involved westward-propagating thrusting of the early Permian basins,

156 with their transformation into foreland systems (Fergusson, 1991; Korsch et al., 2009).

157 The east-west compression of the Hunter-Bowen orogeny has been attributed to 
158 coupling in the subducted and over-riding plates, following further eastward migration

159 of subduction systems located at the edge of Gondwana (Rosenbaum et al., 2012).

160 However, another alternative is the docking of a Permian intra-oceanic island arc

161 terrane against the eastern edge of Gondwana (Harrington, 1983). Following the

162 Hunter-Bowen orogeny, Triassic to Jurassic depositional basins developed over the 163 NEO.

165 3. The Port Macquarie serpentinite mélange

166 3.1. Geological background

167 The Port Macquarie area is mostly underlain by a 'broken formation' of

168 Palaeozoic units intercalated with the Port Macquarie serpentinite mélange (Leitch,

169 1974; Barron et al., 1976; Och et al., 2007). Common lithologies are metabasalts, with

170 preservation of pillow structures quite widespread, cherts bearing radiolarians and

171 conodonts, and clastic sedimentary rocks that are mostly volcanic lithic arenites (e.g.,

172 Barron et al., 1976; Leitch, 1980). The easternmost of these along the coast are well

173 exposed, and have been named the Watonga Formation (Leitch, 1980). Based on

174 radiolarian and conodont assemblages, Watonga Formation metacherts have been

175 ascribed Ordovician and Devonian ages (Ishiga et al., 1988; Och et al., 2007a). The

176 Tacking Point Gabbro (31 28'24’S 15256'14'E; Och et al., 2007b) was intruded into

177 Watonga Formation metabasalts and cherts, and based on U-Pb zircon dating, is

178 Devonian in age, (Buckman et al., in preparation). Zircon U-Pb dating on

179 detrital/volcanic zircons from a Watonga Formation volcanic lithic arenite from Green

180 Point (31²5’49”S 15255’26”E; Parker, 2010) indicates a maximum

181 mid-Carboniferous depositional age (Buckman et al., in preparation). Thus the

182 Watonga Formation contains rocks of different age and origin. Similar 
183 metasedimentary units inland are poorly exposed. They are either intruded or

184 intercalated with metadolerite, and were assigned to the 'middle' Palaeozoic

185 Touchwood Formation and the Lower Permian Thrumster slate by Leitch (1980).

186 Cropping out sporadically along the shoreline from Town Beach $\left(31^{\circ} 25^{\prime} 47^{\prime \prime} \mathrm{S}\right.$

$187152^{\circ} 55^{\prime} 20^{\prime \prime} \mathrm{E}$ ) to just north of Tacking point (around $31^{\circ} 28^{\prime} 13^{\prime} \mathrm{S} 152^{\circ} 56^{\prime} 05^{\prime \prime} \mathrm{E}$ ) is the

188 Port Macquarie serpentinite mélange (Barron et al., 1976; Och et al., 2007b). Recent

189 mapping suggests that the mélange structurally overlies the parts of the Watonga

190 Formation that consist of lithic arenites with Carboniferous detrital zircons (Buckman

191 et al., in preparation). However, inland, because of poor exposure, the relationship of

192 the mélange to the Touchwood Formation and the Thrumster slate has not been

193 elucidated. These Ordovician to Lower Permian tectonic assemblages, including the

194 serpentinites, are overlain unconformably by Early Triassic alluvial deposits and

195 volcanic rocks of the Lorne Basin (Leitch, 1980; Och et al., 2007b; Pratt, 2010). Thus

196 the last major tectonic event involved the intercalation of Devonian to Lower Permian

197 rocks, and must have occurred after deposition of the Early Permian Thrumster slate

198 and before the deposition of the unconformable Lorne Basin Early Triassic rocks

199 (timescale of Gradstein et al., 2012). Some deformation continued after deposition of

200 the Lorne basin, as shown by folding in its eastern parts (Pratt, 2010).

202 3.3. Rocky Beach blueschist and eclogite blocks

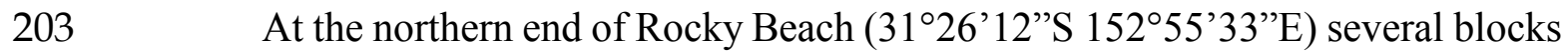

204 of high-pressure metamorphic rocks up to $10 \mathrm{~m}$ diameter occur within the Port

205 Macquarie serpentinite mélange (Barron et al., 1976; Och et al., 2003, 2007b). One ca.

$20610 \mathrm{~m}$ block of massive blueschist preserves relict pillow structures in its centre, which

207 towards its margin becomes obliterated by higher strain with the development of a

208 glaucophane schistosity. Such rocks are clearly derived from basaltic protoliths. Given 
209 the protolith nature and the low temperature of metamorphism, such rocks are unlikely

210 to carry zircon and were not investigated in this study. Other blocks consist of

211 blueschist with thin, folded layers of eclogite (Fig. 2a; also illustrated by Och et al.

2122003 as their Fig. 2). This block was the source of our samples eclogite 21-06 and

213 blueschist RB-2. There are also blocks of widely retrogressed, high-pressure

214 metamorphic rocks that also have compositional layering (Fig. 2b; our sample RB-3 is

215 from this block). These retrogressed rocks still contain some relict garnet, but the

216 omphacite and/or glaucophane have been entirely replaced by chlorite. Consequently,

217 it is uncertain whether they originally carried blueschist or eclogite facies assemblages.

218 The blocks with compositional layering are likely to have been derived from

219 sedimentary or volcano-sedimentary protoliths. Thus we targeted them for zircon U-Pb

220 dating, because even if it transpired that the metamorphic grade was too low to grow

221 zircon in situ during high-pressure metamorphism, their youngest detrital zircons

222 would define a maximum possible age for that metamorphism.

223 The whole rock geochemical analyses for eclogite 21-06, blueschist RB-2 and

224 retrogressed high-pressure rock RB-3 are presented in Table 1. Their high MgO +

$225 \mathrm{Fe}_{2} \mathrm{O}_{3}, \mathrm{Cr}(400-206 \mathrm{ppm})$ and $\mathrm{Ni}(68-64 \mathrm{ppm})$ contents show dominance of mafic

226 material. However, high $\mathrm{K}_{2} \mathrm{O}(3.63-1.02 \mathrm{wt} \%), \mathrm{Ba}(1102-401 \mathrm{ppm})$ and overall low

$227 \mathrm{SiO}_{2}$ contents (down to $43.88 \mathrm{wt} \%$ ) suggest that the protoliths were not fresh mafic

228 rocks. Furthermore $\mathrm{Zr}$ content is high (275-103 ppm). Retrogressed sample RB-3 has

229 an anomalously high $\mathrm{TiO}_{2}$ content $(3.37 \mathrm{wt} \%)$. The block from where RB-3 was

230 sampled contains ilmenite + rutile segregations (sample RB-4, see below).

231 Over-representation of such segregation material in the bulk sample is a likely reason

232 for the high $\mathrm{TiO}_{2}$ content. Combining the interlayered nature of eclogite and blueschist

233 (21-06 and RB-2), with the whole rock chemistry, we propose that the protoliths of the 
234 dated samples are dominated by altered mafic volcanic material, with an additional

235 detrital component.

236 In the Rocky Beach blueschist facies rocks, the main assemblage is

237 glaucophane + garnet + phengite \pm lawsonite \pm albite + titanite + pyrite. In the eclogites

238 lawsonite is present, but there has been extensive retrogression of the garnet and

239 omphacite, with the development of chlorite. Both Barron et al. (1976) and Och et al.

240 (2003) recorded complex metamorphic textures, with several generations of

241 high-pressure mineral growth, during the development syn-kinematic fabrics. The

242 blueschists are traversed by thin albite-bearing veins. For the Rocky Beach

243 lawsonite-bearing blueschist rocks Price (1991) estimated pressure-temperature

244 conditions of ca. $0.75-0.6 \mathrm{GPa}$ and $270-200^{\circ} \mathrm{C}$, whereas Och et al. (2003) suggested

245 somewhat higher temperatures of $450-350^{\circ} \mathrm{C}$, in a similar pressure regime. Och et al.

246 (2003) suggested appreciably high temperatures and pressures for the Rocky Beach

247 eclogites (see Discussion).

\section{Zircon petrography, U-Pb dating and rare earth element chemistry}

\subsection{Analytical methods}

Zircon concentrates were prepared by standard heavy liquid and isodynamic

252 separation techniques at the mineral separation laboratory of the Research School of

253 Earth Sciences, the Australian National University (ANU). The location of the three 254 samples investigated are shown in Figs. 2a,b). The concentrates were hand picked

255 under a binocular microscope, and the selected grains were cast in epoxy resin discs

256 together with the zircon Temora 1 reference material (Black et al., 2003). The discs

257 were ground to reveal mid-sections through the grains and then polished. The grains

258 were documented with reflected and transmitted light photomicrographs (Fig. 3), and 
259 also by cathodoluminescence (CL) imaging. CL images of representative zircons are

260 shown in Fig. 4.

261 Zircons were U-Pb dated on the SHRIMP II instruments at the University of

262 Hiroshima and Geoscience Australia (Canberra). Analytical protocols followed

263 Williams (1998), and reduction of the raw data used the ANU software 'PRAWN' and

264 'Llead'. ${ }^{206} \mathrm{~Pb} /{ }^{238} \mathrm{U}$ of the unknowns was calibrated using measurements of the Temora

2652 reference material (U-Pb ages concordant at $417 \mathrm{Ma}$; Black et al., 2003) interleaved

266 with analyses of the unknowns. $U$ and Th abundance was calibrated using

267 measurement of the reference zircon SL13 (U=238 p.p.m.) located in a set-up mount.

268 The zircon U-Th- $\mathrm{Pb}$ data are summarised in Table 2. The reduced and calibrated data

269 were assessed and plotted using the ISOPLOT program of Ludwig (2003).

270 Rare earth element (REE) analyses of some zircons were undertaken using the

271 Hiroshima University SHRIMP II instrument, and for others the REE and other trace

272 element abundances were acquired by LA-ICP-MS at ANU. The SHRIMP analyses

273 were undertaken in the normal mass-resolution mode ( 6000), and according to the

274 method outlined by Maas et al. (1992) and Hidaka et al. (2002). Abundances were

275 calibrated using count rates obtained from analyses of the zircon standard 91500

276 (Wiedenbeck et al., 2004). The zircon LA-ICP-MS data was acquired according to the

277 methodology given by Eggins et al. (1998). It was calibrated using interspersed

278 analyses of NIST610 glass. As a check on the accuracy of elemental abundance, SL13

279 zircons were analysed twice as unknowns, and yielded an average $U$ abundance of 230

280 p.p.m., compared to the accepted isotope dilution value of $238 \mathrm{ppm}$. REE analyses are

281 summarised in Table 3. 
Three blueschist-eclogite samples from Rocky Beach (samples 21-06, RB-2 and RB-3; Fig. 2a,b) all gave low yields of zircons ( $<50$ grains per kilogram), and display the same range of morphologies. The exteriors of all grains are rounded, and regardless of their age show pitting of their surface, which is attributed to abrasion within sedimentary systems (Fig. 3a-c). Their rounded and pitted form contrasts strongly with igneous zircons in Port Macquarie rocks, such as from the Tacking Point gabbro (31 $28^{\circ} 24^{\prime \prime} S 152^{\circ} 56^{\prime} 14^{\prime \prime}$; ; Och et al., 2007b), at the southern end of the Port Macquarie coastal tract. In such rocks, the zircons are not pitted and sharp clear boundaries are preserved between the grain facets (Fig. 3d). Furthermore, the exterior form of the zircons in Rocky Beach samples differs from definite synhigh-temperature eclogite facies metamorphic zircon, for example from the Franklin metamorphics of Tasmania (Fig. 3e). In such eclogites, metamorphic zircons have clean, exterior surfaces, with common development of multifaceted habits. Therefore, combined with evidence from CL images for the lack of overgrowths developed in situ, we conclude that the zircons from both Rocky Beach blueschist and eclogite facies metamorphic rocks are best interpreted as detrital grains, largely devoid of coatings of new, syn-metamorphic growth. sample 21-06, 1 in sample RB-3; Figs. 4a,b) are structurally simple, slightly rounded euhedral prisms with well-preserved oscillatory zoning. Multiple analyses on these

304 three grains yielded a weighted mean ${ }^{206} \mathrm{~Pb} /{ }^{238} \mathrm{U}$ age of $251 \pm 6 \mathrm{Ma}(\mathrm{MSWD}=0.16$; Fig.

305 5a; Induan = earliest Triassic, according to the timescale of Gradstein et al., 2012).

306 These grains are interpreted to be detrital in origin and derived from an Induan igneous

307 source. Their age falls at the start of the youngest arc magmatism in the New England

308 Orogen. Seven 380-340 Ma grains (Middle Devonian to Middle Carboniferous) are 
310 zoning (Figs. 4c and 5a). Older grains form more complex populations, with many

311 grains being composite, with magmatic cores and younger magmatic overgrowths, or

312 more commonly rounded cores of oscillatory-zoned zircon with overgrowths that

313 appear homogeneous or sector-zoned in CL images. In all such cases our interpretation

314 is that the metamorphic overgrowths have been abraded and partly removed during

315 sedimentary transport, showing that they carry a record of distal metamorphism in their

316 source region, and not in situ metamorphism in the Rocky Beach blueschist-eclogite

317 facies blocks. This is illustrated by RB-2 grains 2 and 4 and RB-3 grain 3 (Figs. 4d,e,f).

318 In Neoproterozoic RB-2 grain 2, a 735 Ma core has a 594 Ma overgrowth, partly

319 removed by abrasion such that the core occurs at half of the grain's surface. For RB-3

320 grain 3, a rounded oscillatory core (not dated) has a sector-zoned ca. $405 \mathrm{Ma}$ (early

321 Devonian) rim, which is partly abraded. At the right hand grain margin (Fig. 4f), the

322 inclusion of another mineral previously entirely enclosed, is now at the grain surface.

323 Thus the eclogite and blueschist samples all yielded essentially the same zircon

324 populations, both in terms of habit, structure and age distribution.

\subsection{Zircon REE chemistry}

REE analyses of zircons from the blueschist and eclogite facies rocks were

328 undertaken to ascertain which phases they equilibrated with (chondrite-normalised

329 data are plotted in Fig. 5b). 251 Ma oscillatory zoned prism grains 4 and 7 from sample

330 21-06 display strong enrichment of the heavy over the light REE, with a negative Eu

331 anomaly. This indicates the youngest grains grew in the presence of plagioclase and

332 absence of garnet, showing that they did not grow during high-pressure

333 metamorphism. A similar REE pattern is found for sample 21-06 Carboniferous grains

33410,11 and 14 (Fig. 5b). Other REE analyses focussed on metamorphic (albeit abraded) 
335 overgrowths, to ascertain if they provide evidence of blueschist-eclogite facies

336 metamorphism at an earlier time, i.e. in accord with suggestion that it occurred in the

337 early Palaeozoic (Och et al., 2003, 2007b, 2010 and references therein). Most of these

338 rims, ranging in age from ca. $405 \mathrm{Ma}$ on RB-3 grain 3 to ca. $595 \mathrm{Ma}$ Neoproterozoic

339 ones such as on RB-2 grains 2 and 4 (Figs. 4d and e) show similar heavy REE enriched

340 patterns with negative Eu anomalies, demonstrating that during metamorphism they

341 grew in a low pressure plagioclase-present, garnet-absent environment (Rubatto,

342 2002). The only exceptions are the ca. 560 Ma rim on RB-2 grain 6 and the entire 1100

343 Ma 21-06 grain 15, which both show depressed heavy REE abundances but still carry

344 negative Eu anomalies (Fig. 5b). These indicate source region metamorphisms at

345 medium pressures with both garnet and plagioclase present (Rubatto, 2002). Thus

346 none of the dated zircons from the blueschist-eclogite blocks carry a depressed heavy

347 REE without a Eu anomaly signature, which would be indicative of high-pressure

348 metamorphism (example from an eclogite facies metamorphic zircon from the

349 Franklin metamorphics is shown in Fig. 5b for comparison).

351 5. Titanite-rutile $\mathbf{U}-\mathbf{P b}$ dating

352 5.1. Sampling and analytical method

353 Rocky beach eclogites locally contain porphyroblasts of titanium rich phases

354 which were identified by use of a Niton hand-held portable XRF analyser. One $>1 \mathrm{~cm}$

355 diameter porphyroblast (sample RB-4; Fig. 2b,c) was sawn from a retrogressed high

356 pressure metamorphic block, cast in an epoxy resin disc along with the ANU Khan

357 titanite standard and polished for phase identification via EDS spectral analysis with a

358 scanning electron microscope. The phases were then dated by the LA-ICP-MS method. 
LA-ICP-MS analysis was undertaken at GEMOC at Macquarie University,

360 Sydney using a New Wave UP213 Nd:YAG $213 \mathrm{~nm}$ laser ablation system coupled to

361 an Agilent 7700 quadrupole ICP-MS. The setup for LA-ICP-MS analysis and

362 analytical procedure were described by Jackson et al. (2004) and R19 rutile (489.5 \pm

363 0.9 Ma; Zack et al., 2011) was used as a calibration standard.

\subsection{Titanite-rutile segregation petrography and $\mathrm{U}-\mathrm{Pb}$ dating}

A backscattered electron image of part of the segregation is shown in Fig. 6.

367 The main phases present are titanite and rutile, seemingly in equilibrium with each

368 other. Sulphides, chlorite, glaucophane and ilmenite also occur.

The U-Pb data are summarised in Table 4. The high ${ }^{207} \mathrm{~Pb} /{ }^{206} \mathrm{~Pb}$ combined with

$370 \quad$ low ${ }^{238} \mathrm{U} /{ }^{206} \mathrm{~Pb}$ in all the analyses shows that $\mathrm{Pb}$ in the rutiles and titanites are

371 dominated by 'common' non-radiogenic $\mathrm{Pb}$. In order to obtain a radiogenic age

372 avoiding the problem of isobaric mercury $\left({ }^{204} \mathrm{Hg}\right)$ interference at the ${ }^{204} \mathrm{~Pb}$ mass when

373 undertaking a correction for common $\mathrm{Pb}$, the data was regressed in ${ }^{207} \mathrm{~Pb} /{ }^{206} \mathrm{~Pb}$ versus

$374{ }^{238} \mathrm{U} /{ }^{206} \mathrm{~Pb}$ space, as shown in Fig. 7. In this approach, where the regression line

375 intercepts the ${ }^{207} \mathrm{~Pb} /{ }^{206} \mathrm{~Pb}$ axis $\left({ }^{238} \mathrm{U} /{ }^{206} \mathrm{~Pb}=0\right)$, it gives the ${ }^{207} \mathrm{~Pb} /{ }^{206} \mathrm{~Pb}$ composition of

376 the common $\mathrm{Pb}$. Where the regression line gives a lower intercept with concordia, it

377 signifies the $\mathrm{U}-\mathrm{Pb}$ radiogenic component in the rutiles and titanites, which in this case

378 is interpreted as the timing of metamorphic growth. All the data fall along a single

379 regression line, with an $\mathrm{MSWD}=0.71$. Given that most of the coexisting rutiles and

380 titanites have $<1 \mathrm{ppm}$, each determination has a large analytical error and is dominated

381 by the non-radiogenic 'common' $\mathrm{Pb}$. Hence, there is a long extrapolation of a

382 regression line with a broad error envelope to a lower concordia intercept. The

383 'closure' temperature of both titanite and rutile are ca. $600^{\circ} \mathrm{C}$ (Scott and St-Onge, 
384 1995; Cherniak, 2000), which is above the peak metamorphic temperature of these

385 rocks. Therefore the lower concordia intercept of $332 \pm 140 \mathrm{Ma}$ (95\% confidence) is

386 interpreted as giving the age of metamorphic rutile + titanite growth, but with poor

387 precision.

388

389 6.1. Garnet rare earth element chemistry

390 6.1. Sampling and analytical method

391 Fragments of garnet grains were cast in an epoxy resin disc and polished to

392 reveal cross sections for analysis. They were analysed by the LA-ICP-MS method at

393 GEMOC at Macquarie University, Sydney using a New Wave UP213 Nd:YAG 213

394 nm laser ablation system coupled to an Agilent 7700 quadrupole ICP-MS. The setup

395 for LA-ICP-MS analysis and analytical procedure were described by Jackson et al.

396 (2004) and NIST610 glass was used as a calibration standard. REE analyses of 21-06

397 and RB-2 garnets are summarised in Table 3.

\subsection{Results}

$400 \quad$ Overall the garnet REE abundances are low, but relative to chondrite, the heavy

401 REE are enriched and the light REE are depleted (Fig. 5b). There are no Eu anomalies,

402 indicating that the garnet grew in a plagioclase-free environment, during high pressure 403 metamorphism.

405 7. Discussion

406 7.1. Interpretation of the garnet and zircon rare earth element signatures and the 407 zircon ages 
With two exceptions (see below) all zircons in samples 21-06, RB-2 and RB-3

409 are strongly enriched in the heavy REE and depleted in the light REE relative to

410 chondrite, and show negative Eu anomalies (Fig. 5b). These patterns and abundances

411 are coincident with magmatic zircons grown from common granitic melts, in the

412 presence of plagioclase (Belousova et al., 2002). The only zircons that equilibrated

413 with garnet (based on lesser enrichment of the heavy REE) are 21-06 grain 15 (a 1100

414 Ma low Th/U oval grain), and RB-2 analysis 6.1 (a 560 Ma abraded overgrowth; Fig.

415 5b). However, both these show negative Eu anomalies, indicating equilibration with

416 plagioclase. Therefore they did not grow in situ in a plagioclase-free high-pressure

417 metamorphic environment, but instead are detrital grains reflecting lower pressure

418 metamorphism in the sediment source regions. In contrast, the 21-06 and RB-2 garnets

419 do not show Eu anomalies and thus did not equilibrate with plagioclase. Consequently,

420 none of zircons grew in equilibrium with the high pressure metamorphic garnet.

421 Instead, they are interpreted as detrital grains, thereby they only give a maximum age

422 for the high-pressure metamorphism.

\subsection{Timing of high-pressure metamorphism}

At Green Point $\left(31^{\circ} 25^{\prime} 49^{\prime \prime} \mathrm{S} 152^{\circ} 55^{\prime} 26^{\prime \prime} \mathrm{E}\right)$ the Port Macquarie serpentinite

426 mélange carrying the high-pressure rocks is in tectonic contact with low metamorphic

427 grade Carboniferous volcanic lithic arenites previously ascribed to the upper portion of

428 the Watonga Formation (Buckman et al., in preparation). In the south at Tacking Point

429 the serpentinites are in tectonic contact with an Ordovician-Devonian metachert and

430 Devonian igneous complex (Buckman et al., in preparation). On the basis that these

431 tectonic contacts are not entirely late faults much younger than upper crustal

432 emplacement of the serpentinite with its high-pressure inclusions, these field 
433 relationships would argue that the Port Macquarie serpentinite mélange is Late

434 Carboniferous or younger. In the southern part of the Port Macquarie area, Early

435 Triassic, $>220 \mathrm{Ma}$ alluvial sedimentary rocks of the Lorne Basin unconformably

436 overlie serpentinites, giving the minimum age for the high pressure metamorphism

437 (Leitch, 1980; Och et al., 2007b; Pratt, 2010).

438 Zircons from sample 21-06 were concentrated in 2010, whereas zircon

439 concentrates for the other two samples RB-2 and RB-3 were prepared in 2011. All

440 samples gave a small yield of zircons ( $<50$ grains per kilogram), with similar

441 morphology and age distribution, including young, ca. $250 \mathrm{Ma}$ zircons. Given that the

442 zircon concentrates were prepared at two different times, and the zircons hand-picked

443 and cast into epoxy mounts at different times, we consider it unlikely that the ca. 250

444 Ma zircons are laboratory contaminants, but are the youngest detrital grains from these

445 samples. Even if these ca. 250 Ma grains are discounted (such as being sourced from

446 the thin albite pegmatite veins), it should be noted that the majority of the grains are

447 Middle Carboniferous or Devonian in age, and are thus still appreciably younger than

448 the Ordovician age for the high-pressure metamorphism proposed by Och et al. (2003,

$4492007 b, 2010)$. Thus from geological relationships and from our zircon studies we

450 conclude that the high-pressure metamorphism occurred before deposition of the Early

451 Triassic Lorne basin rocks and probably after $251 \mathrm{Ma}$, but certainly after ca. 340 Ma.

453 7.2. Contradiction between zircon U-Pb and mica K-Ar and Ar-Ar ages?

454 The interpretation of the zircon data as indicating late Palaeozoic to earliest

455 Triassic high-pressure metamorphism contradicts the interpretation of older, $>400 \mathrm{Ma}$,

456 Ar-Ar and K-Ar mica ages as indicating growth during Ordovician high-pressure

457 metamorphism (Fukui et al., 1995; Hyodo, 2008; Och et al., 2003, 2007a, 2010). 
458 However, high pressure metamorphic terranes commonly give anomalously old Ar-Ar

459 mica ages, relative to ages of high pressure metamorphism established by U-Pb zircon

460 and Sm-Nd mineral isochrons (Kelley et al., 1994). The apparently too-old ages are

461 most likely the result of excess argon. This is despite the fact that the mica samples

462 might yield apparently acceptable stepped-heating plateau. Three examples of this

463 follow: (a) In the ultra high-pressure terrane of Dabie Shan, China, Ar-Ar mica ages

464 are Neoproterozoic, whereas U-Pb and Sm/Nd ages are ca. $220 \mathrm{Ma}$ (Li et al., 1999).

465 The macroscopic reason for this was investigated by Li et al. (1999). They noted that

466 high-pressure rocks from the same outcrop failed to equilibrate Ar-isotopes between

467 each other, on a centimetre to metre scale. They proposed that excess ${ }^{40} \mathrm{Ar}$ was derived

468 internally from the high-pressure rocks, through the degassing of early-generation

469 (detrital) minerals, but was not completely expelled from the rock body prior to its

470 closure for the isotopic system. This is accord with the ultra-high-pressure

471 metasedimentary rocks containing early Palaeozoic and Precambrian detrital zircons

472 (Maruyama et al., 1998), demonstrating the presence of old crustal material in these

473 rocks. (b) The high pressure rocks of the Dora Maira Massif in the western Alps give

474 ca. $100 \mathrm{Ma}$ Ar-Ar ages, conflicting with ca. $40 \mathrm{Ma}$ zircon U-Pb ages (Arnaud and

475 Kelley, 1995). (c) In a study of blueschist and low-temperature eclogite facies rocks

476 from the Tavsanli Zone of NW Turkey (Sherlock and Kelley, 2002), samples were

477 analysed by the UV Laser Ablation method and yielded apparent ages ranging from 72

478 to $155 \mathrm{Ma}$. Detailed in situ intra-grain profiling of phengites, and analyses of

479 sodic-amphibole, lawsonite, quartz and garnet, provided the detailed spatial

480 distribution of excess argon within different minerals in the same samples. This

481 revealed that they acted as near closed systems where excess argon was preferentially

482 partitioned into phengite. They concluded that excess argon was derived in situ, rather

483 than having been introduced by fluids. Therefore, Sherlock and Kelley (2002) 
484 proposed that a combination of stepped-heating and in situ laser spot analyses is

485 required to provide the most reliable understanding of Ar-Ar ages from high pressure

486 metamorphic rocks. They also advised that any Ar-Ar mica ages that are older than the

$487 \mathrm{Rb}-\mathrm{Sr}$ ages on the same micas should be regarded as suspect, and likely to contain

488 excess argon. In the case of the Port Macquarie Rocky Beach eclogites and blueschists,

489 to our knowledge, $\mathrm{Rb} / \mathrm{Sr}$ mica ages have not been published. Such $\mathrm{Rb} / \mathrm{Sr}$ mica ages

490 would help to clarify the meaning of the Ar-Ar ages. Given the general problems of

491 excess argon in low-temperature, high-pressure, Ar-Ar mica geochronology (e.g., Li et

492 al., 1999; Arnauld and Kelley, 1995; Sherlock and Kelley, 2002) and the present lack

493 of $\mathrm{Rb} / \mathrm{Sr}$ dating of the Rocky Beach phengites, we contend that our zircon ages give a

494 more robust constraint on the timing of metamorphism than the available mica ages.

7.3. Appraisal of conditions of the high-pressure metamorphism at Port Macquarie

Appraisal of the glaucophane schists suggests pressures of ca. 0.7-0.6 GPa,

498 with temperatures of $450-350^{\circ} \mathrm{C}$ (Och et al., 2003). These conditions coincide with the

499 stability field of glaucophane-bearing assemblages of Maresch (1977) and are in

500 accord with albite being present with the glaucophane (Och et al., 2003). The low

501 temperature for the blueschists is in accord with the widespread coexistence of

502 lawsonite + glaucophane (Barron et al., 1976; Och et al., 2003), because lawsonite is

503 generally regarded as breaking-down above ca. $400^{\circ} \mathrm{C}$ at these pressures (Newton and

504 Kennedy, 1963; Carson et al., 2000). Thus overall, the Port Macquarie glaucophane

505 schist assemblages record low grade, only moderate high-pressure regimes. This

506 regime is typical for blueschists from the upper parts of subduction zones, such as in

507 the Central Franciscan of California (Oh et al., 1991). 
Associated with the Rocky Beach blueschists are eclogites, which can occur

509 together as thin interfolded layers (Fig. 2a). This has been recorded in other low-grade

510 high-pressure rocks, such as in the Franciscan of California (Oh et al., 1991; their Fig.

511 2). They demonstrated that at low grade, the development of glaucophane-dominated

512 blueschists versus omphacite-bearing eclogites is controlled by variations in

$513 \mathrm{Mn} /(\mathrm{Mn}+\mathrm{Fe})$ in bulk compositions.

514 Presently, the only constraint on the pressure-temperature conditions for the

515 Rocky Beach eclogite assemblages are the coexistence of lawsonite with garnet +

516 omphacite, together with a single estimate of ca. $560^{\circ} \mathrm{C}$ from garnet-omphacite $\mathrm{Fe}-\mathrm{Mg}$

517 cation exchange thermometry (Och et al., 2003). Och et al. (2003) based this

518 temperature on a single pair of garnet-omphacite analyses (Tables 1 and 2 of Och et al.,

519 2003). These Tables indicate that there is considerable variation in $\mathrm{Fe} / \mathrm{Mg}$ between

520 different garnet and omphacite analyses. By using different permutations of the

521 published analyses this would lead to possible calculated temperatures between

$522900-300^{\circ} \mathrm{C}$ at $0.7-0.6 \mathrm{GPa}$ (calculated by the Excel ${ }^{\mathrm{TM}}$ spreadsheet PX-NORM of

523 Sturm, 2003). Och et al. (2003) did not explain why one particular mineral pair giving

$524560^{\circ} \mathrm{C}$ was chosen. Furthermore, we note the rather modest $\mathrm{Al}_{2} \mathrm{O}_{3}$ content (mostly

$52510-7 \mathrm{wt} \%$ ) of the Port Macquarie omphacites, which is similar to those from other low

526 grade $\left(<1 \mathrm{GPa},<450^{\circ} \mathrm{C}\right)$ eclogites (e.g., from the Franciscan - Oh et al., 1991), rather

527 than those encountered $>1.0 \mathrm{GPa}$ medium to high temperature eclogites. Therefore, the

528 suggestion of a much higher temperature $\left(560^{\circ} \mathrm{C}\right)$ and pressure $(>1.5 \mathrm{GPa})$ for the

529 Rocky Beach eclogites compared with the blueschists needs to be substantiated.

530 Instead, we consider it most likely that the eclogites formed within the same low

531 temperature, moderately high-pressure conditions as the blueschists, with the

532 eclogite-blueschist transition governed by bulk composition. Supporting this

533 interpretation are; the intimate interlayering of eclogites with blueschists (samples 
534 21-06 and RB-2; Fig. 2a), the three times higher $\mathrm{Mn} /(\mathrm{Mn}+\mathrm{Fe})$ of the eclogite (Table 1),

535 and as presented in Och et al. (2003) the stability of lawsonite with omphacite and 536 garnet.

537 If all the blueschist and eclogite facies rocks formed at low grade conditions at 538 only $<450^{\circ} \mathrm{C}$, it is unlikely that new in situ metamorphic zircon overgrowths would

539 have developed during the high-pressure metamorphism. Thus the grains from

540 eclogites show the same pitted surfaces as those from the blueschists, without the

541 development of euhedral, faceted metamorphic overgrowths, as is seen on zircons

542 definitely grown during higher temperature eclogite facies metamorphism (Fig. 3).

544 7.3. Late Palaeozoic blueschist-eclogite facies metamorphism at Port Macquarie and

545 the evolution of the New England Orogen and eastern Gondwana

546 The Port Macquarie serpentinite mélange is an isolated occurrence on the

547 coast, and there is no proven connection with the Great Serpentine Belt of the

548 Peel-Manning fault system inland (Fig. 1a). Thus given the geological complexity of

549 the New England Orogen, with several Devonian-Permian arc-accretionary

550 assemblages present, we do not presume here a Late Palaeozoic to earliest Triassic age

551 for the crustal emplacement of the Great Serpentine Belt, and our following discussion

552 on tectonic significance will be based solely on our data from the Port Macquarie

553 serpentinite.

554 In the Permo-Triassic, eastwards migration of arc activity meant that the

555 Carboniferous Tablelands-Wandilla subduction complex was the basement of the

556 250-225 Ma north-south components of the New England batholith and related

557 volcanic rocks (Fig 1a; Cawood et al., 2011; Rosenbaum et al., 2012). We note that the

558 youngest detrital zircons in our eclogite and blueschist facies samples coincide with 
559 the inception of this arc activity, which is likely to be their ultimate source. At the

560 extreme eastern fringe of Australia in south-eastern Queensland is the enigmatic

561 Gympie terrane, which seems to be a Permian island arc assemblage (Sivell and

562 McCulloch, 2001). Prior to opening of the Tasman Sea, perhaps this was contiguous

563 with the Brook Street Terrane in New Zealand and the Teremba Terrane of New

564 Caledonia (Harrington, 1983; Spandler et al., 2005). We propose that the emplacement

565 of Port Macquarie serpentinite mélange carrying the eclogites and blueschists was

566 related to subduction at the margin of Gondwana and/or to the juxtaposition a

567 Palaeopacific Ocean Permian island arc (now represented by the dispersed Gympie,

568 Brook Street and Teremba Terranes) against an Andean eastern Australian margin

569 (represented by the 260-230 Ma New England Batholith and volcanic components,

570 Fig. 1a; Cawood et al., 2011; Rosenbaum et al., 2012). This event might be the driving

571 force behind the Permo-Triassic Hunter Bowen orogeny (Carey and Browne, 1938),

572 during which basement Carboniferous Tamworth Belt forearc rocks were thrust

573 westwards over Permian back-arc basin rocks of the eastern fringes of the

574 Sydney-Gunnedah-Bowen basins (Fig. 1a).

576 8. Conclusions

577 (1) Three samples of metasedimentary eclogite and blueschist facies rocks from the Port

578 Macquarie serpentinite mélange at Rocky beach yielded detrital zircons with ages from $>3000$ 579 to $251 \mathrm{Ma}$.

580 (2) Metamorphic overgrowths developed in situ during high-pressure metamorphism were not

581 detected. This is in accord with reappraisal of the conditions of the blueschist and eclogite

582 facies metamorphism, for which all the available information indicate low-grade for both, with 
583 temperatures of $<450^{\circ} \mathrm{C}$ at $0.7-0.6 \mathrm{GPa}$. If so, this would be in accord with the lack of

584 syn-eclogite facies metamorphic zircon growth.

585 (3) Hence, from the U-Pb zircon studies, the youngest detrital grains (251 Ma) give the

586 maximum age for the high-pressure metamorphism. Lorne Basin alluvial sedimentary rocks

587 ( $\geq 220 \mathrm{Ma}$ ) deposited unconformably on Port Macquarie serpentinite mélange give the

588 minimum age for the high-pressure metamorphism.

589 (4) The zircon $\mathrm{U}-\mathrm{Pb}$ age constraint for the high-pressure metamorphism and the previously

590 reported Ordovician Ar-Ar mica ages for this event are contradictory. Our explanation for this

591 is that the micas contain excess ${ }^{40} \mathrm{Ar}$, as is commonly found in micas from low-grade

592 high-pressure metamorphic terranes. This can be tested by $\mathrm{Rb} / \mathrm{Sr}$ dating of the micas with

593 apparent Ordovician Ar-Ar ages.

594 (5) The new age constraints suggest that the high-pressure metamorphic event at Port

595 Macquarie occurred during late Palaeozoic to earliest Triassic subduction at the Gondwanan

596 margin. Cessation of the high pressure metamorphism and emplacement into the crust of the

597 serpentinite mélange carrying blocks of the high pressure rocks might have been related to

598 juxtaposition of an exotic arc terrane (now represented by the Gympie terrane of southern

599 Queensland) rafted into a 260-230 Ma Andean arc at the margin of Gondwana. This coincides

600 with the timing of the 260-230 Ma Hunter-Bowen orogeny.

601

\section{Acknowledgments}

603 This project was supported by the University of Wollongong GeoQuest fund, a Japan travel

604 grant to A. Nutman from the Australian Academy of Science s and Hiroshima University.

605 Geoscience Australia is thanked for permission to undertake further studies of eclogite facies

606 zircons from the Franklin metamorphics of Tasmania. Shane Paxton of the Australian National 
607 University is thanked for zircon separations. The paper benefited from the constructive reviews

608 by Peter Cawood and Chris Clark.

609

\section{References}

Aitchison, J.C., Flood, P.G., 1992. Early Permian transform margin development of the 1385-1391.

Aitchison, J.C., Ireland, T.R., 1995. Age profile of ophiolitic rocks across the late Palaeozoic New England Orogen, New South Wales: Implications for tectonic models. Australian Journal of Earth Sciences 42, 11-23.

Aitchison, J.C., Stratford, J.M.C., Buckman, S., 1997. Geology of the Upper Barnard Region, evidence of Early Permian oblique-slip faulting along the Peel-Manning Fault System, in: Ashley, P.M., Flood, P.G. (Eds.), Tectonics and Metallogenesis of the New England Orogen Alan H. Voisey Memorial Volume. Geological Society of Australia Special Publication 19, pp. 188-196.

Aitchison, J.C., Blake, M.C.Jr., Flood, P.G., Jayko, A.S., 1994. Paleozoic ophiolitic assemblages within the southern New England orogen of eastern Australia: Implications for growth of the Gondwana margin. Tectonics 13, 1135-1149.

Arnaud, N. O., Kelly, S., 1995, Evidence for excess Ar during high pressure metamorphism in the Dora-Maira (western Alps, Italy), using an ultraviolet laser ablation microprobe ${ }^{40} \mathrm{Ar} /{ }^{39} \mathrm{Ar}$ technique: Contributions to Mineralogy Petrology 121, 1-11.

Barron, B.J., Scheibner, E., Slansky, E. 1976. A dismembered ophiolite suite at Port Macquarie, New South Wales. Records of the Geological Survey of New South Wales 18, 69-102.

Belousova, E.A., Griffin, W.L., O’Reilly, S.Y., Fisher, N.I., 2002. Igneous zircon: trace element composition as an indicator of source rock type. Contributions to Mineralogy and Petrology, 143, 602-622.

Benson, W.N., 1913. The geology and petrology of the Great Serpentine Belt of New South Wales. Part II. The geology of the Nundle district. Proceedings of the Linnean Society of New South Wales 38, 569-596. 
Benson, W.N., 1914b. The geology and petrology of the Great Serpentine Belt of New South Wales. Part III. Petrology. Proceedings of the Linnean Society of New South Wales 38, $662-724$.

Benson, W.N., 1915a. The geology and petrology of the Great Serpentine Belt of New South Wales. Part IV. The dolerites, spilites, and keratophyres of the Nundle district. Proceedings of the Linnean Society of New South Wales 40, 121-173.

Benson, W.N., 1915b. The geology and petrology of the Great Serpentine Belt of New South Wales. Part V. The geology of the Tamworth district. Proceedings of the Linnean Society of New South Wales 40, 540-624.

Benson, W.N., 1918. The geology and petrology of the Great Serpentine Belt of New South Wales. Part VIII. The extension of the Great Serpentine Belt from the Nundle district to the coast. Proceedings of the Linnean Society of New South Wales 43, 593-599.

Binns, R.A., 1966. Granitic intrusions and regional metamorphic rocks of Permian age from the Wongwibinda District, north-eastern New South Wales. Journal and Proceedings of the Royal Society of New South Wales 99, 5-35.

Black, L.P., Kamo, S.L., Allen, C.M., Aleinikoff, J.M., Davis, D.W., Korsch, R.J., Foudoulis, C., 2003. TEMORA 1: A new zircon standard for Phanerozoic U-Pb geochronology. Chemical Geology 200.

Bruce, M.C., Niu, Y., 2000. Early Permian supra-subduction assemblage of the South Island Terrane, Percy Isles, New England fold belt, Queensland. Australian Journal of Earth Sciences 47, 1077-1085.

Bryant, C.J., Arculus, R.J., Chappell, B.W., 1997. Clarence River Supersuite: $250 \mathrm{Ma}$ Cordilleran tonalitic I-type intrusions in eastern Australia. Journal of Petrology 38, 975-1001.

Buckman, S., Nutman, A.P., Parker, Bembridge, S., Aitchison, J., Hidaka, H., Kamiichi, T., in preparation. The Palaeozoic Watonga Formation and Tacking Point Gabbro, Port Macquarie, eastern most Australia, and their relationship with a serpentinite mélange. To be submitted to Australian Journal of Earth Sciences by March 2013.

Carey, S.W., Browne, W. R. 1938. Review of the Carboniferous stratigraphy, tectonics and palaeogeography of New South Wales and Queensland. Journal and Proceedings of the Linnean Society of New South Wales 71, 591-614.

Carson, C.J., Clarke, G.L., Powell, R., 2000. Hydration of eclogites, Pan Peninsula, New Caledonia. Journal of Metamorphic Geology 18, 79-90.

Cawood, P.A., 1982. Structural relations in the subduction complex of the Paleozoic New England Fold Belt, eastern Australia. Journal of Geology 90, 381-392. 
674 Cawood, P.A., 1984. The development of the SW Pacific margin of Gondwana: correlations between the Rangitata and New England orogens. Tectonics 3, 539-553.

Cawood, P.A., 2005. Terra Australis Orogen: Rodinia breakup and development of the Pacific and Iapetus margins of Gondwana during the Neoproterozoic and Paleozoic. Earth Science Reviews 69, 249-279.

Cawood, P.A., Leitch, E.C., Merle, R.E., Nemchin, A., 2011. Orogenesis without collision: Stabilizing the Terra Australis accretionary orogen, eastern Australia. Geological Society America Bulletin 123, 2240-2255.

Collins, W.J., 1991. A reassessment of the "Hunter-Bowen orogeny": tectonic implications for the southern New England fold belt. Australian Journal of Earth Science 38, 409-423.

Collins, W.J., Richards, S.W., 2008. Geodynamic significance of S-type granites in Circum-Pacific orogens. Geology Boulder 36, 559-562.

Dirks, P.H.G.M., Hand, M., Collins, W.J., Offler, R., 1992. Structural-metamorphic evolution of the Tia Complex, New England fold belt; thermal overprint of an accretion-subduction complex in a compressional back-arc setting. Journal of Structural Geology 14, 669-688.

Fergusson, C.L., 1991. Thin-skinned thrusting in the northern New England Orogen, central Queensland, Australia. Tectonics 10, 797-806.

Fergusson, C.L., Nutman, A.P., Kamiichi, T., Hidaka, H. (submitted): Evolution of a Cambrian active continental margin: the Delarmerian-Lachlan connection in southeastern Australia from a zircon perspective. Gondwana Research, accepted pending minor revisions.

Flood, R.H., Shaw, S.E., 1975. A cordierite-bearing granite suite from the New England Batholith, N.S.W., Australia. Contributions to Mineralogy and Petrology 52, 157-164. 
Flood, P.G., Aitchison, J.C., 1988. Tectonostratigraphic terranes of the southern part of the New England Orogen, In: Kleeman, J.D. (Ed.), New England Orogen: Tectonics and Metallogenesis. Univ. N. Engl., Dep. Geol. and Geophys., Armidale, pp. 7-10.

Fukui, S., Watanabe, T., Ithaya, T., Leitch, E. C., 1995. Middle Ordovician high PT metamorphic rocks in eastern Australia: Evidence from K-Ar ages. Tectonics 14, 1014-1020.

Gilotti, J.A., Nutman, A.P., Brueckner, H.K., 2004. Devonian to Carboniferous collision in the Greenland Caledonides: U-Pb zircon and $\mathrm{Sm}-\mathrm{Nd}$ ages of high-pressure and ultrahigh-pressure metamorphism. Contributions to Mineralogy and Petrology 148, 216-235.

Glen, R. A., 2005. The Tasmanides of eastern Australia. In: Terrane Processes at the Margins of Gondwana, edited by Vaughan, A.P.M., Leat, P.T., Pankhurst, R.J. Geological Society Special Publication 246, 23-96.

Gradstein, F.M., Ogg, J.G., Schmitz, M., Ogg, G., 2012. The Geologic Time Scale 2012. Elsevier, Amsterdam, 1142 pp.

Harrington HJ 1983. Correlation of the Permian and Triassic Gympie Terrane of Queensland with the Brook Street and Maitai Terranes of New Zealand. In: Murray CG pref. Permian geology of Queensland. Brisbane, Australia, Geological Society of Australia. Pp. 431-436.

Harrington, H.J., Korsch, R.J., 1985. Late Permian to Cainozoic tectonics of the New England Orogen. Australian Journal of Earth Sciences 32, 181-203.

Hermann, J., Rubatto, D., Korsakov, A., Shatsky, V.S., 2001. Multiple zircon growth during fast exhumation of diamondiferous, deeply subducted continental crust (Kokchetav Massif, Kazakstan): Contributions to Mineralogy and Petrology 141, 66-82.

Hidaka, H., Shimizu, H., Adachi, M., 2002. U-Pb geochronology and REE geochemistry of zircons from Palaeoproterozoic paragneiss clasts in the Mesozoic Kamiaso conglomerate, central Japan: evidence for an Archean provenance. Chemical Geology 187, 279-293.

Holcombe, R.J., Stephens, C.J., Fielding, C.R., Gust, D., Little, T.A., Sliwa, R., Kassan, J., McPhie, J., Ewart, A., 1997. Tectonic evolution of the northern New England Fold Belt: the Permian-Triassic Hunter-Bowen Event, In: Ashley, P.M., Flood, P.G. (Eds.), Tectonics and metallogenesis of the New England orogen. Special Publication Geological Society of Australia, Armidale, pp. 52-65.

Hyodo, H., 2008. Laser probe ${ }^{40} \mathrm{Ar} /{ }^{39} \mathrm{Ar}$ dating: history and development from a technical perspective. Gondwana Research 14, 609-616. 
742 Ishiga, H., Leitch, E.C., Watanabe, T., Naka, T., Iwasaki, M., 1988. Radiolarian and conodont biostratigraphy of siliceous rocks from the New England Fold Belt. Australian Journal of Earth Sciences 35, 73-80.

Jackson, S.E., Pearson, N.J., Griffin, W.L., Belousova, E.A., 2004. The application of laser ablation microprobe-inductively coupled plasma-mass spectrometry (LAM-ICPMS) to in situ U-Pb zircon geochronology. Chemical Geology 211, 47-69.

Jenkins, R.B., Landenberger, B., Collins, W.J., 2002. Late Palaeozoic retreating and advancing subduction boundary in the New England Fold Belt, New South Wales. Australian Journal of Earth Sciences 49, 467-489.

Kelly, S.P., Arnaud, N.O., Okay, A.I., 1994. Anomalously old Ar-Ar ages in high pressure metamorphic terrains. Mineralogical Magazine, 58A, 468-469.

Korsch, R.J., Harrington, H.J., 1981. Stratigraphic and structural synthesis of the New England Orogen. Journal of the Geological Society of Australia 28, 205-226.

Korsch, R.J., Adams, C.J., Black, L.P., Foster, D.A., Fraser, G.L., Murray, C.G., Foudoulis, C., Griffin, W.L., 2009. Geochronology and provenance of the Late Paleozoic accretionary wedge and Gympie Terrane, New England Orogen, eastern Australia. Australian Journal of Earth Sciences 56, 655-685.

Leitch, E.C., 1974. The geological development of the southern part of the New England

Leitch, E.C., 1975. Plate tectonic interpretation of the Paleozoic history of the New England Fold Belt. Geol. Soc. Am. Bull. 86, 141-144.

Leitch, E.C., 1980. Rock units, structure, and metamorphism of the Port Macquaire Block, eastern New England fold belt. Proceedings of the Linnean Society of New South Wales 104, 3-4.

Leitch, E.C., Cawood, P.A., 1980. Olistoliths and debris flow deposits at ancient consuming plate margins; an eastern Australian example. Sedimentary Geology 25, 1-2.

Lennox, P.G., Offler, R., 2009. Kinematic history of serpentinites in the faulted margins of isotopic systematics of ultrahigh-pressure metamorphic rocks in the Dabie-Sulu Belt, Central China: A retrospective view. International Geology Review 41, 1114-1124. 
Ludwig, K.R., 2003. Isoplot 3.0: A geochronological toolkit for Microsof Excel, Berkeley Geochronological Center Special Publication 4, 70 pp., Berkeley Geochronological Center, Berkeley, California.

Maas, R., Kinny, P.D., Williams, I.S., Froude, D.O., Compston, W., 1992. The Earth's oldest known crust: A geochronological and geochemical study of 3900-4200 Ma old detrital zircons from Mt. Narryer and Jack Hills, Western Australia. Geochimica et Cosmochimica Acta 56, 1281-1300.

Maresch, W.V., 1977. Experimental studies on glaucophane: An analysis of present knowledge. Tectonophysics 43, 109-125.

Maruyama, S., Tabata, H., Nutman, A.P., Morikawa, T., Liou, J.G., 1998. SHRIMP U/Pb geochronology of ultrahigh-pressure metamorphic rocks of the Dabie Mountains, central China. Continental Dynamics 3, 72-85.

McPhie, J., Fergusson, C.L., 1983. Dextral movement on the Demon Fault, northeastern New South Wales: A reassessment (Australia). Journal of the Proceedings of the Royal Society of New South Wales 116, 123-127.

Murray, C.G., Fergusson, C.L., Flood, P.G., Whitaker, W.G., Korsch, R.J., 1987. Plate tectonic model for the Carboniferous evolution of the New England Fold Belt (Australia), Aust. J. Earth Sci., 34(2), 213-236.

Newton, R.C., Kennedy, G.C., 1963. Some equilibrium reactions in the join $\mathrm{CaAl}_{2} \mathrm{Si}_{2} \mathrm{O}_{8}-\mathrm{H}_{2} \mathrm{O}$. Journal of Geophysical Research 68, 2967-2983.

Nutman, A.P., Kalsbeek, K., Friend, C.R.L., 2008 The Nagssugtoqidian orogen in South-East Greenland: Evidence for Paleoproterozoic collision and plate assembly. American Journal of Science 308, 529-572.

Och, D.J., Leitch, E.C., Caprarelli, G., Watanabe, T., 2003. Blueschist and eclogite in tectonic mélange, Port Macquarie, New South Wales, Australia. Mineralogical Magazine 67, 609-624.

Och, D.J., Percival, I.G., Leitch, E.C., 2007a. Ordovician Conodonts from the Watonga Formation, Port Macquarie, Northeast New South Wales. Proceedings of the Linnean Society of New South Wales 128, 209-216.

Och, D.J., Leitch, E.C., Caprarelli, G., 2007b. Geological units of the Port Macquarie-Tacking Point tract, north-eastern Port Macquarie Block, Mid North Coast region of New South Wales. Geological Survey of New South Wales Quarterly Notes 126, 19 pp. 
807

808

809

810

811

812

813

814

815

816

817

818

819

820

821

822

Och, D.J., Zwingmann, H.Z., Phillips, G., Leitch, E.C. 2010. Implications for K-Ar dating on fuchsite mica from Rocky Beach, Port Macquarie. In: Quinn, C.D., Dazcko, N.R. (Eds), Abstracts of the Specialist Group in Tectonics and Structural Geology Conference. Port Macquarie, February 2010; Geological Society of Australia Abstracts, No. 97, p. 49.

Offler, R., Williams, A.J., 1987. Evidence for sinistral movement on the Peel fault system in serpentinites, Glenrock Station, N.S.W. Geodynamics Series 19, 141-151.

Oh, C.H., Liou, J.G., Maruyama, S. 1991. Low-temperature eclogites and eclogite schists in Mn-rich metabasites in Ward Creek, California; Mn and Fe effects on the transition between blueschist and eclogite. Journal of Petrology 32, 275-301.

Parker, J. 2010. Analysis of the Port Macquarie serpentinite mélange. University of Wollongong Honours Thesis, 100 pp.

Phillips, G., Offler, R., 2011. Contrasting modes of eclogite and blueschist exhumation in a retreating subduction system; the Tasmanides, Australia. Gondwana Research 19, 800-811.

Pratt, G.W., 2010. A revised Triassic stratigraphy for the Lorne Basin, NSW. Geological Survey of New South Wales Quarterly Notes 134, 35 pp.

Price, T.M., 1991. The geology of the Port Macquarie Complex New South Wales. B.Sc. Honours thesis, University of Sydney.

Roberts, J., Engel, B.A., 1987. Depositional and tectonic history of the southern New England Orogen. Australian Journal of Earth Sciences 34, 1-20.

Roberts, J., James, L., 2010. Stratigraphic relationships of Carboniferous volcanogenic successions in the Clifton-Carroll Block and Werrie Syncline, northern Tamworth Belt, southern New England Orogen. Australian Journal of Earth Sciences 57, 193-205.

Roberts, J., Offler, R., Fanning, M., 2004. Upper Carboniferous to Lower Permian volcanic successions of the Carroll-Nandewar region, northern Tamworth Belt, southern New England Orogen, Australia. Australian Journal of Earth Sciences 51, 205-232.

Roberts, J., Offler, R., Fanning, M., 2006. Carboniferous to Lower Permian stratigraphy of the southern Tamworth Belt, southern New England Orogen, Australia: boundary sequences of the Werrie and Rouchel blocks. Australian Journal of Earth Sciences 53, 249-284.

Roberts, J., Leitch, E.C., Lennox, P.G., Offler, R., 1995. Devonian-Carboniferous stratigraphy of the southern Hastings Block, New England Orogen, eastern Australia. Australian Journal of Earth Sciences 42, 609-633. 
841 Rosenbaum, G., Li, P., Rubatto, D., 2012. The contorted New England Orogen (eastern Australia): New evidence from U-Pb geochronology of early Permian granitoids. Tectonics 31, TC1006.

Rubatto, D., 2002. Zircon trace element geochemistry: partitioning with garnet and the link between U-Pb ages and metamorphism. Chemical Geology 184, 123-138.

Sano, S., Offler, R. Hyodo, H., Watanabe, T., 2004. Geochemistry and chronology of tectonic blocks in serpentinite mélange of the southern New England Fold Belt, NSW, Australia. Gondwana Research 7, 817-831.

Scott, D.J., St-Onge, M.R., 1995. Constraints on $\mathrm{Pb}$ closure temperature in titanite based on rocks from the Ungava orogen, Canada: Implications for U-Pb geochronology and P-T-t path determinations. Geology 23, 1123-1126.

Shaw, S.E., Flood, R.H., 1974. Eclogite from serpentinite near Attunga, New South Wales. Journal of the Geological Society of Australia 21, 377-385.

Sherlock, S., Kelley, S., 2002. Excess argon evolution in HP-LT rocks: a UVLAMP study of phengite and K-free minerals, NW Turkey. Chemical Geology 182, 619-636.

Sivell, W.J., McCulloch, M.T., 2001. Geochemical and Nd-isotopic systematics of the Permo-Triassic Gympie Group, southeast Queensland. Australian Journal of Earth Sciences 48, 377-393.

Spaggiari, C.V., Gray, D.R., Foster, D.A., 2004. Ophiolite accretion in the Lachlan Orogen,

Watanabe, T., Leitch, E.C., Fanning, M., 1997. The age and tectonic significance of Southeastern Australia. Journal of Structural Geology 26, 87-112.

Spandler, C., Worden, K., Arculus, R., Eggins, S., 2005. Igneous rocks of the Brook Street Terrane, New Zealand: Implications for Permian tectonics of eastern Gondwana and magma genesis in modern intra-oceanic volcanic arcs. New Zealand Journal of Geology \& Geophysics 48, 167-183.

Sturm, R., 2003. PX-NOM - an interactive spreadsheet program for the computation of lawsonite eclogite and high temperature eclogite blocks in serpentine mélange from the southern New England Fold Belt, Eastern Australia. P. 110 in: IEC 97, Terra Nova.

Wiedenbeck, M., Hanchar, J.M., Peck, W.H., Sylvester, P., Valley, J., Whitehouse, M., Kronz, A., Morishita, Y., Nasdala, L., Fiebig, J., Franchi, I., Girard, J.-P., Greenwood, R.C., Hinton, R., Kita, N., Mason, P.R.D., Norman, M., Ogasawara, M., Piccoli, P.M., Rhede, D., Satoh, H., Schulz-Dobrick, B., Skår, O., Spicuzza, M.J., Terada, K., Tindle, 
A., Togashi, S., Vennemann, T., Xie, Q., Zheng, Y.-F., 2004. Further characterisation of the 91500 zircon crystal. Geostandards and Geoanalytical Research 28, 9-39.

Williams, I.S., 1998. U-Th-Pb geochronology by ion microprobe. In Applications of Short Course Vol. 7, 1-35.

881 Zack, T., Stockli, D.F., Luvizotto, G.L., Barth, M.G., Belousova, E., Wolfe, M.R., Hinton, R.W., 2011. In situ U-Pb rutile dating by LA-ICP-MS: ${ }^{208} \mathrm{~Pb}$ correction and prospects for geological applications. Contributions to Mineralogy and Petrology 162, 515-530. 


\section{Figure captions}

886 Figure 1. (a) Geological sketch map of the southern end of northeastern New South Wales.

(b) Synthesis of New England Orogen terranes in northeastern New South Wales and south-eastern Queensland.

Figure 2. Field photographs of eclogite and blueschist blocks at the northern end of Rocky Beach, Port Macquarie. Location of analysed samples is indicated.

Figure 3. Transmitted light photomicrographs of zircons. (a-c) Grains from Rocky Beach eclogite and blueschist facies rocks. (d) Example of an igneous zircon from the Devonian Tacking Point Gabbro, Port Macquarie. (e) Examples of syn-metamorphic (low HREE, no Eu negative anomaly) eclogite facies zircons from the Franklin metamorphics, Tasmania.

Figure 4. Cathodoluminescence images of representative zircons from Rock Beach eclogite and blueschist facies rocks.

Figure 5. Analytical data for minerals from Rocky Beach eclogite and blueschist facies rocks. (a) Summary Tera-Wasserburg ${ }^{238} \mathrm{U} /{ }^{206} \mathrm{~Pb}$ versus ${ }^{207} \mathrm{~Pb} /{ }^{206} \mathrm{~Pb}$ plot for zircons. Analytical errors are depicted at the $2 \sigma$ level. (b) Chondrite-normalised plot of REE analyses for zircons and garnets. Noted analyses are as follows: (i) 21-06 oval low Th/U ca. 1100 Ma zircon 15.1 and (ii) RB-2 abraded ca. 560 Ma metamorphic rim have negative Eu anomalies and low HREE abundance, showing they equilibrated with plagioclase and garnet; (iii) example of a 500 Ma syn-eclogite facies zircon from the

\section{Table Captions}

914 Table 1. Whole rock XRF geochemical analyses.

915 Table 2. Summary SHRIMP zircon U-Th-Pb data

916 Table 3. SHRIMP and LA-ICP-MS zircon and garnet rare earth element analyses.

917 Table 4. Summary LA-ICP-MS rutile and titanite U-Pb data 


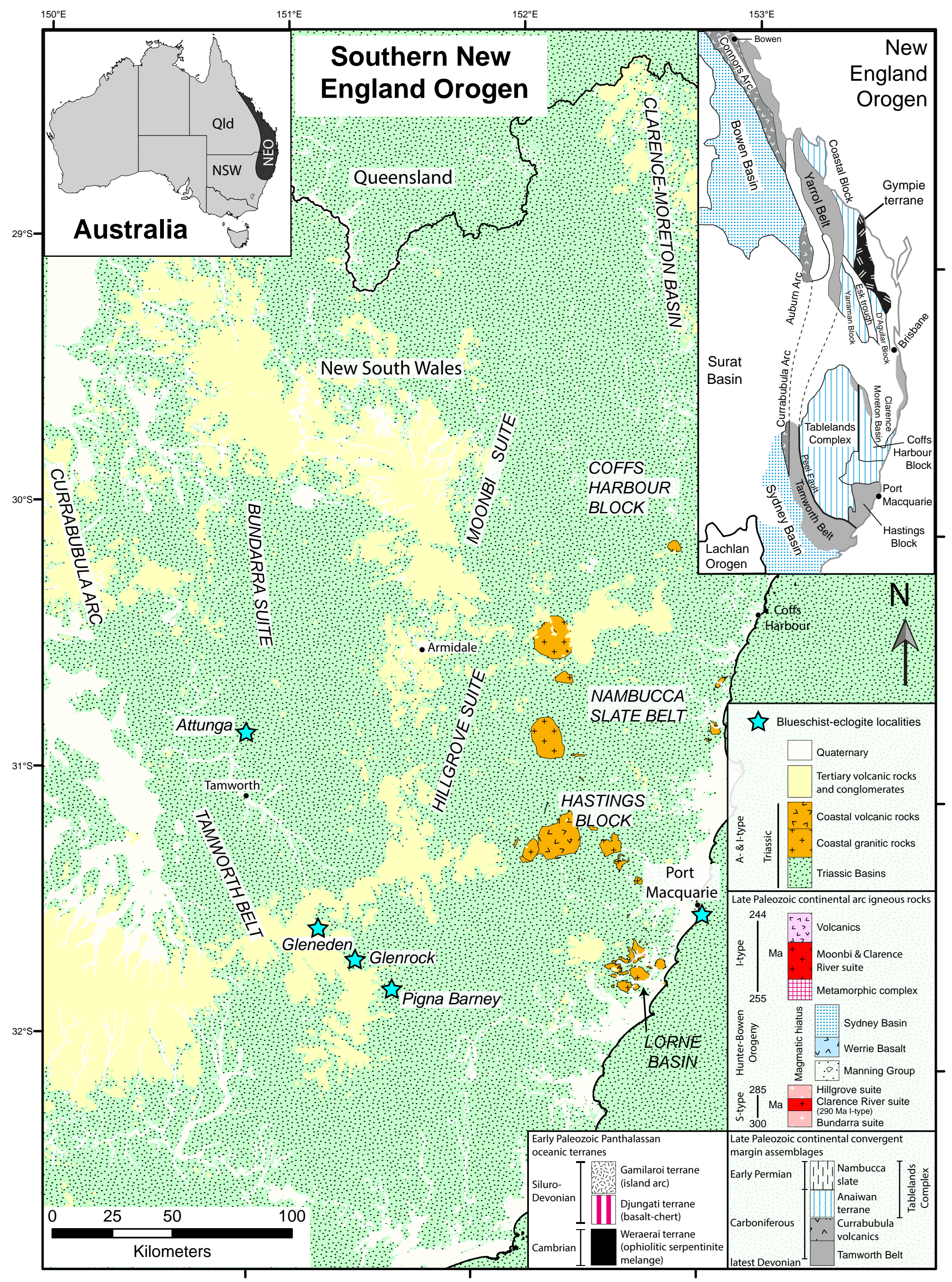




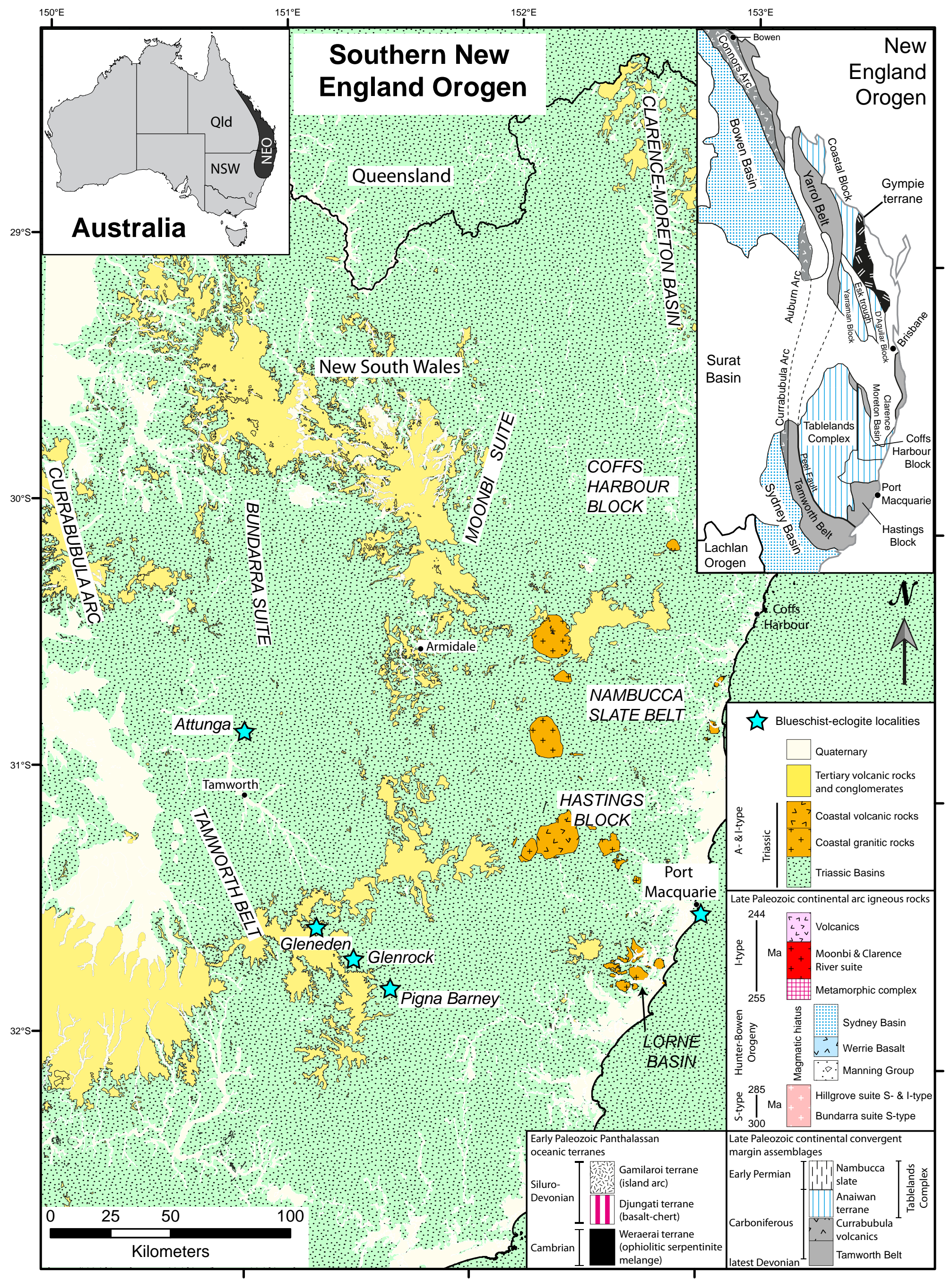




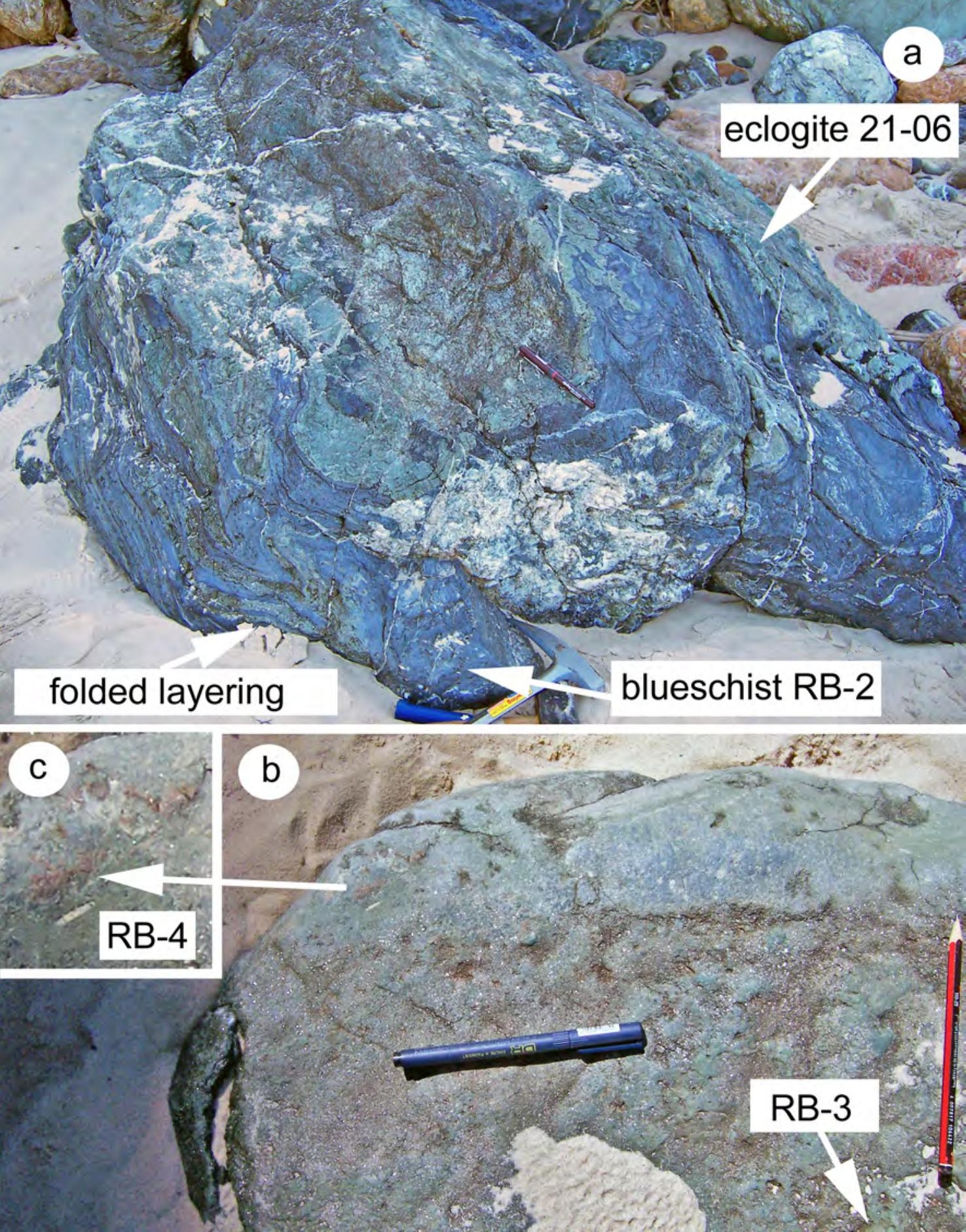




\section{RB-3}

grain 1

$250 \mathrm{Ma}$

a

RB-3

grain 2

$350 \mathrm{Ma}$

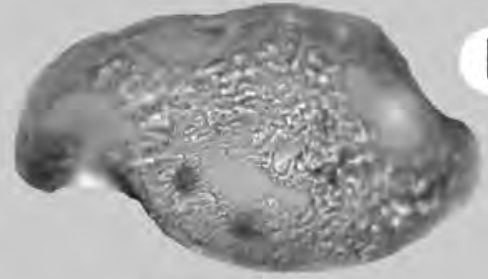

b

RB-2 grain 2 $595 \mathrm{Ma}$ rim

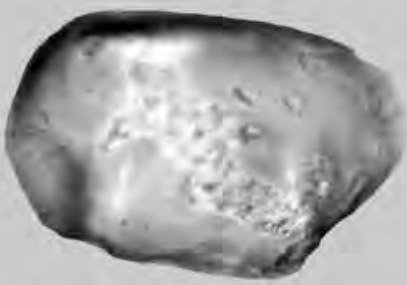

C

Tacking Point

Gabbro magmatic zircon

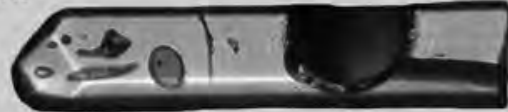

syn-eclogite facies (500 Ma) metamorphic zircons, Tasmania

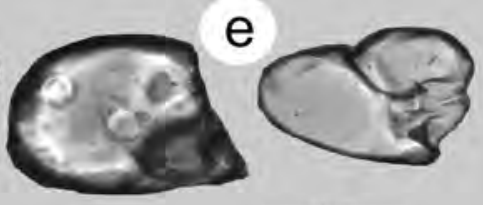


21-06 grain 7

a

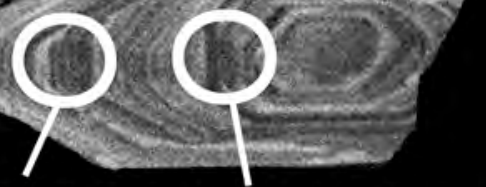

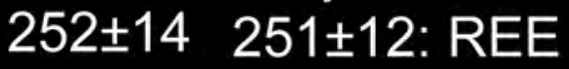

RB3 grain 2

C

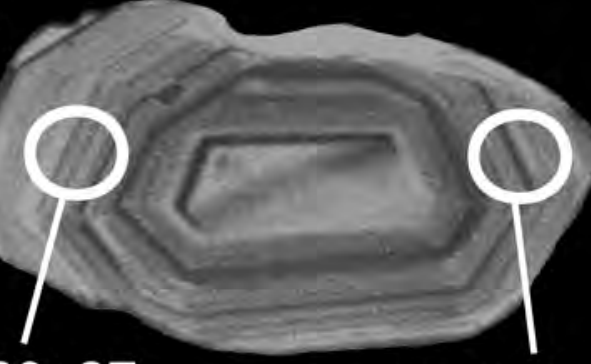

$369 \pm 27$

RB2 grain 4

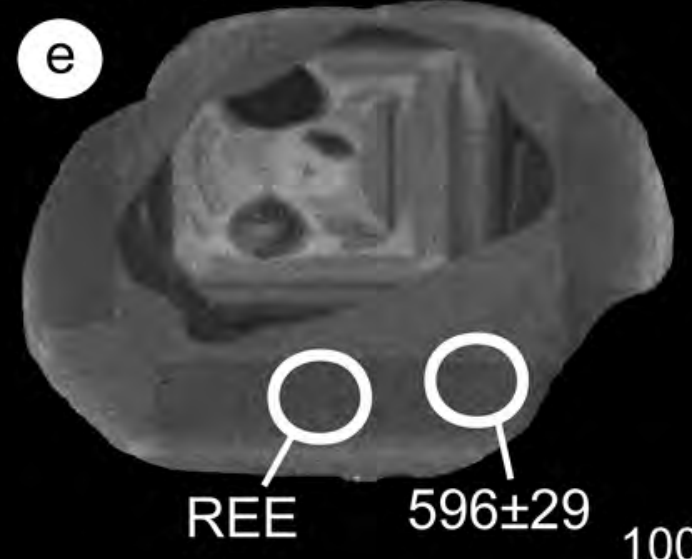

$100 \mu \mathrm{m}$
RB3 grain 1

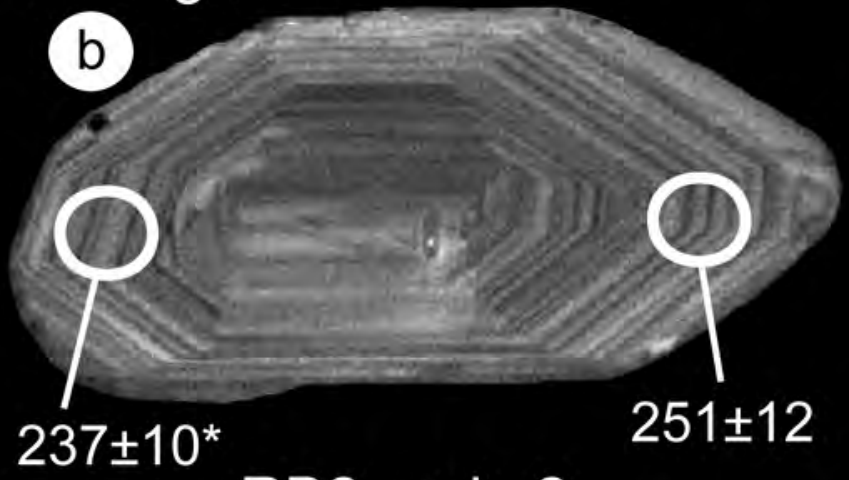

RB2 grain 2

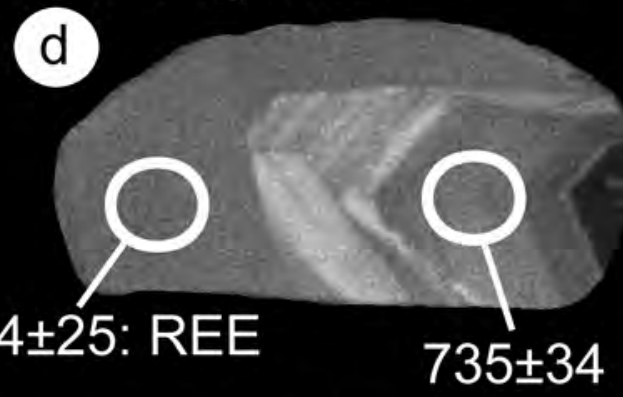

RB3 grain 3

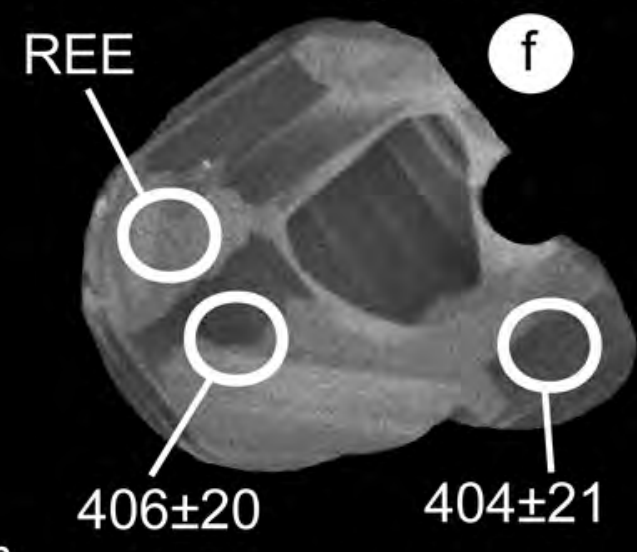

$2 \sigma$ errors on ages $(\mathrm{Ma})$ 

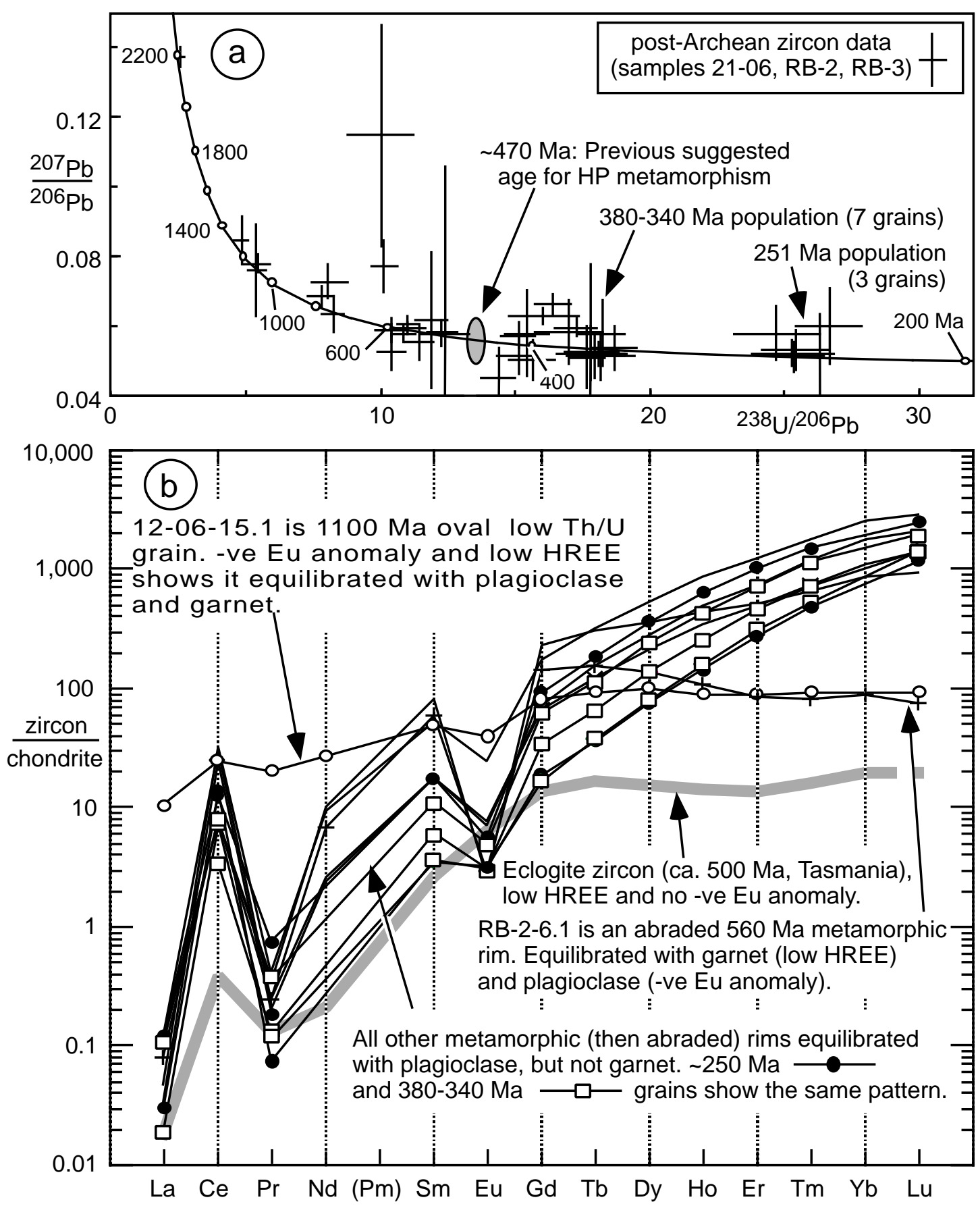


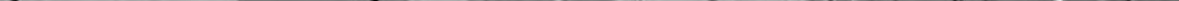


$1 . 0 \longdiv { \square }$

common $\mathrm{Pb}$ composition

\section{RB4 rutiles and titanites}

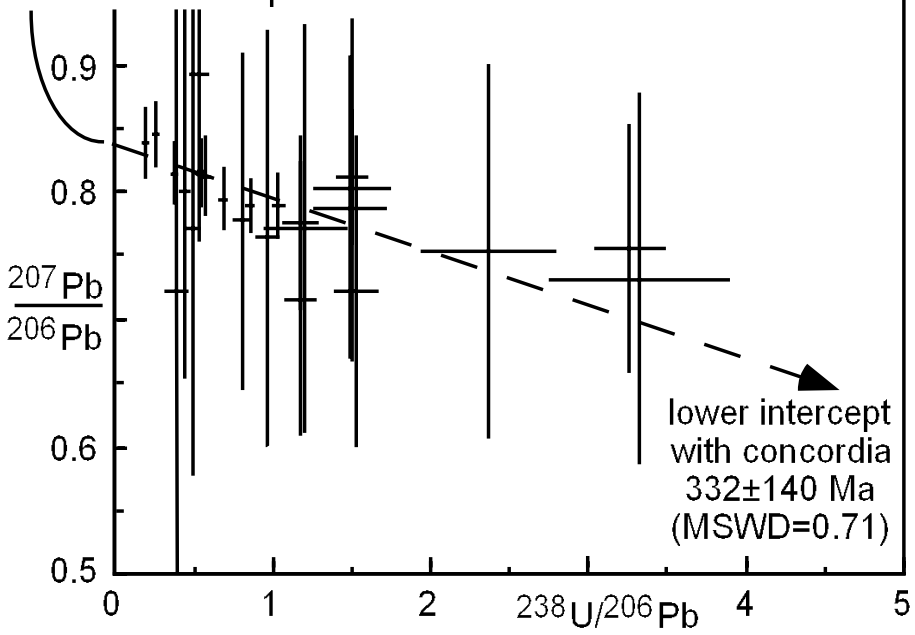




\begin{tabular}{|c|c|c|c|}
\hline & $\begin{array}{l}21-06 \\
\text { eclogite }\end{array}$ & $\begin{array}{c}\text { RB-2 } \\
\text { blueschist }\end{array}$ & $\begin{array}{c}\text { RB-3 } \\
\text { retrogressed }\end{array}$ \\
\hline$\overline{\mathrm{SiO} 2}$ & 43.88 & 52.14 & 44.74 \\
\hline TiO2 & 1.65 & 1.62 & 3.37 \\
\hline $\mathrm{A} 12 \mathrm{O} 3$ & 14.16 & 9.91 & 14.30 \\
\hline $\mathrm{Fe} 2 \mathrm{O} 3$ & 14.39 & 14.90 & 12.76 \\
\hline $\mathrm{MnO}$ & 0.39 & 0.15 & 0.13 \\
\hline $\mathrm{MgO}$ & 5.75 & 7.29 & 5.59 \\
\hline $\mathrm{CaO}$ & 9.15 & 4.54 & 9.58 \\
\hline $\mathrm{Na} 2 \mathrm{O}$ & 2.09 & 4.74 & 3.36 \\
\hline $\mathrm{K} 2 \mathrm{O}$ & 3.63 & 1.02 & 2.59 \\
\hline P2O5 & 0.52 & 0.16 & 0.40 \\
\hline SO3 & 3.44 & 1.43 & 0.12 \\
\hline LOI & 4.51 & 3.34 & 2.75 \\
\hline Total & 103.55 & 101.22 & 99.70 \\
\hline $\mathrm{Mn} /(\mathrm{Mn}+\mathrm{Fe})$ & 0.030 & 0.011 & 0.011 \\
\hline V & 416 & 400 & 329 \\
\hline $\mathrm{Cr}$ & 260 & 161 & 138 \\
\hline $\mathrm{Ni}$ & 64 & 68 & 67 \\
\hline $\mathrm{Cu}$ & 111 & 27 & 23 \\
\hline $\mathrm{Zn}$ & 120 & 165 & 73 \\
\hline $\mathrm{Rb}$ & 61 & 18 & 48 \\
\hline $\mathrm{Sr}$ & 182 & 96 & 185 \\
\hline $\mathrm{Ba}$ & 1102 & 401 & 1072 \\
\hline Y & 44 & 28 & 33 \\
\hline $\mathrm{Zr}$ & 106 & 103 & 275 \\
\hline $\mathrm{Nb}$ & 16 & 11 & 36 \\
\hline La & $<2$ & $<2$ & 24 \\
\hline $\mathrm{Ce}$ & 20 & 2 & 93 \\
\hline $\mathrm{Hf}$ & 4 & 3 & 5 \\
\hline
\end{tabular}




\begin{tabular}{|c|c|c|c|c|c|c|c|c|c|c|}
\hline \multirow{2}{*}{\multicolumn{2}{|c|}{$\begin{array}{l}\text { Labels site } \\
\text { RB-2 blueschist }\end{array}$}} & \multirow[t]{2}{*}{$\mathrm{U} / \mathrm{ppm}$} & \multirow[t]{2}{*}{$\mathrm{Th} / \mathrm{ppm}$} & \multirow[t]{2}{*}{$\mathrm{Th} / \mathrm{U}$} & \multirow[t]{2}{*}{ f206\% } & ${ }^{238} \mathrm{U} /{ }^{206} \mathrm{~Pb}$ & ${ }^{207} \mathrm{~Pb} /{ }^{206} \mathrm{~Pb}$ & age ${ }^{206} \mathrm{~Pb} /{ }^{238} \mathrm{U}$ & age ${ }^{207} \mathrm{~Pb} /{ }^{206} \mathrm{~Pb}$ & \multirow[t]{2}{*}{$\%$ conc } \\
\hline & & & & & & & & & & \\
\hline 1.1 & $\mathrm{e}, \mathrm{osc}, \mathrm{p}, \mathrm{fr}$ & 146 & 69 & 0.48 & $<0.001$ & $15.10 \pm 0.32$ & $0.0574 \pm 0.0018$ & $414 \pm 9$ & & \\
\hline 1.2 & $\mathrm{e}, \mathrm{osc}, \mathrm{p}, \mathrm{fr}$ & 196 & 117 & 0.60 & $<0.001$ & $14.18 \pm 0.31$ & $0.0564 \pm 0.0011$ & $441 \pm 9$ & & \\
\hline 2.1 & r,h,ov & 185 & 33 & 0.18 & 2.277 & $10.13 \pm 0.23$ & $0.0772 \pm 0.0024$ & $594 \pm 13$ & & \\
\hline 2.2 & $\mathrm{c}, \mathrm{osc}, \mathrm{ov}$ & 145 & 61 & 0.42 & 1.147 & $8.19 \pm 0.20$ & $0.0682 \pm 0.0018$ & $735 \pm 17$ & & \\
\hline 3.1 & $\mathrm{e}, \mathrm{osc}, \mathrm{p}$ & 630 & 306 & 0.48 & 0.905 & $16.41 \pm 0.34$ & $0.0663 \pm 0.0012$ & $378 \pm 8$ & & \\
\hline 3.2 & $\mathrm{e}, \mathrm{osc}, \mathrm{p}$ & 660 & 343 & 0.52 & 0.246 & $17.23 \pm 0.39$ & $0.0611 \pm 0.0010$ & $363 \pm 8$ & & \\
\hline 4.1 & $\mathrm{r}, \mathrm{h}, \mathrm{ov}$ & 353 & 219 & 0.62 & $<0.001$ & $10.32 \pm 0.27$ & $0.0591 \pm 0.0023$ & $596 \pm 15$ & & \\
\hline 5.1 & $\mathrm{r}, \mathrm{sz}, \mathrm{ov}$ & 135 & 136 & 1.01 & 0.404 & $11.35 \pm 0.25$ & $0.0623 \pm 0.0012$ & $542 \pm 11$ & & \\
\hline 6.1 & $\mathrm{r}, \mathrm{sz}, \mathrm{ov}$ & 381 & 176 & 0.46 & 0.192 & $11.02 \pm 0.21$ & $0.0607 \pm 0.0007$ & $559 \pm 10$ & & \\
\hline 7.1 & $\mathrm{e}, \mathrm{osc}, \mathrm{p}, \mathrm{fr}$ & 103 & 64 & 0.62 & $<0.001$ & $18.36 \pm 0.49$ & $0.0550 \pm 0.0022$ & $344 \pm 9$ & & \\
\hline 7.2 & e,osc,p,fr & 114 & 80 & 0.70 & $<0.001$ & $18.22 \pm 0.42$ & $0.0581 \pm 0.0024$ & $345 \pm 8$ & & \\
\hline \multicolumn{11}{|c|}{ RB-3 eclogite } \\
\hline 1.1 & $\mathrm{e}, \mathrm{osc}, \mathrm{p}$ & 265 & 180 & 0.68 & $<0.001$ & $25.40 \pm 0.60$ & $0.0534 \pm 0.0013$ & $251 \pm 6$ & & \\
\hline 1.2 & $\mathrm{e}, \mathrm{osc}, \mathrm{p}$ & 267 & 184 & 0.69 & 0.146 & $26.66 \pm 0.58$ & $0.0603 \pm 0.0019$ & $237 \pm 5$ & & \\
\hline 2.1 & e,osc,ov & 208 & 125 & 0.60 & $<0.001$ & $18.11 \pm 0.59$ & $0.0553 \pm 0.0014$ & $348 \pm 11$ & & \\
\hline 2.2 & e,osc,ov & 140 & 104 & 0.75 & 0.099 & $16.97 \pm 0.64$ & $0.0599 \pm 0.0030$ & $369 \pm 14$ & & \\
\hline 3.1 & r,sz,ov & 157 & 183 & 1.17 & $<0.001$ & $15.53 \pm 0.41$ & $0.0557 \pm 0.0016$ & $404 \pm 10$ & & \\
\hline 3.2 & $\mathrm{r}, \mathrm{sz}, \mathrm{ov}$ & 76 & 50 & 0.65 & $<0.001$ & $15.41 \pm 0.40$ & $0.0579 \pm 0.0017$ & $406 \pm 10$ & & \\
\hline 4.1 & e,rex,ov & 90 & 3 & 0.03 & $<0.001$ & $4.81 \pm 0.14$ & $0.0847 \pm 0.0034$ & $1218 \pm 31$ & $1309 \pm 79$ & 93 \\
\hline 5.1 & r,h,ov & 139 & 76 & 0.55 & 0.33 & $11.88 \pm 0.26$ & $0.0617 \pm 0.0014$ & $519 \pm 11$ & & \\
\hline 6.1 & e,rex,ov & 64 & 27 & 0.43 & $<0.001$ & $2.02 \pm 0.05$ & $0.1926 \pm 0.0026$ & $2594 \pm 56$ & $2765 \pm 22$ & 94 \\
\hline 7.1 & e,h,ov & 6 & 16 & 2.69 & 7.956 & $9.90 \pm 0.60$ & $0.1221 \pm 0.0144$ & $573 \pm 35$ & & \\
\hline \multicolumn{11}{|c|}{ 21-06 eclogite } \\
\hline 1.1 & h,ov & 374 & 170 & 0.455 & 0.041 & $1.71 \pm 0.05$ & $0.2276 \pm 0.0016$ & $2965 \pm 68$ & $3035 \pm 11$ & 98 \\
\hline 2.1 & $\mathrm{~m}, \mathrm{osc}, \mathrm{p}$ & 145 & 62 & 0.428 & 0.086 & $3.55 \pm 0.14$ & $0.1723 \pm 0.0044$ & $1601 \pm 56$ & $2580 \pm 44$ & 62 \\
\hline 2.2 & $\mathrm{e}, \mathrm{osc}, \mathrm{p}$ & 365 & 171 & 0.468 & 0.052 & $1.96 \pm 0.06$ & $0.1962 \pm 0.0016$ & $2654 \pm 62$ & $2795 \pm 13$ & 95 \\
\hline 3.1 & $\mathrm{c}, \mathrm{osc}, \mathrm{p}$ & 1029 & 1217 & 1.183 & 4.124 & $7.86 \pm 0.32$ & $0.0964 \pm 0.0009$ & $742 \pm 29$ & & \\
\hline 3.2 & $\mathrm{r}, \mathrm{osc}, \mathrm{p}$ & 255 & 139 & 0.543 & $<0.001$ & $15.13 \pm 0.40$ & $0.0538 \pm 0.0014$ & $415 \pm 11$ & & \\
\hline
\end{tabular}




\begin{tabular}{|c|c|c|c|c|c|c|c|c|c|c|c|c|c|}
\hline 4.1 & $\mathrm{e}, \mathrm{osc}, \mathrm{p}$ & 190 & 86 & 0.454 & $<0.001$ & 24.71 & \pm 0.79 & 0.0579 & \pm 0.0029 & 256 & \pm 8 & & \\
\hline 4.2 & $\mathrm{e}, \mathrm{osc}, \mathrm{p}$ & 139 & 64 & 0.462 & $<0.001$ & 25.91 & \pm 1.11 & 0.0533 & \pm 0.0023 & 246 & \pm 10 & & \\
\hline 5.1 & r,hd,ov & 2054 & 732 & 0.356 & 1.612 & 15.87 & \pm 0.63 & 0.0737 & \pm 0.0007 & 388 & \pm 15 & & \\
\hline 5.2 & $\mathrm{c}, \mathrm{osc}, \mathrm{ov}$ & 573 & 237 & 0.413 & 1.156 & 7.78 & \pm 0.25 & 0.0696 & \pm 0.0010 & 771 & \pm 23 & & \\
\hline 6.1 & $\mathrm{c}, \mathrm{osc}, \mathrm{p}$ & 214 & 89 & 0.414 & $<0.001$ & 12.29 & \pm 0.26 & 0.0584 & \pm 0.0016 & 505 & \pm 10 & & \\
\hline 6.2 & $\mathrm{~m}, \mathrm{osc}, \mathrm{p}$ & 114 & 55 & 0.481 & $<0.001$ & 12.40 & \pm 0.35 & 0.0581 & \pm 0.0024 & 501 & \pm 14 & & \\
\hline 7.1 & $\mathrm{e}, \mathrm{osc}, \mathrm{p}, \mathrm{fr}$ & 404 & 282 & 0.698 & $<0.001$ & 25.29 & \pm 0.76 & 0.0530 & \pm 0.0014 & 252 & \pm 7 & & \\
\hline 7.2 & $\mathrm{~m}, \mathrm{osc}, \mathrm{p}$ & 416 & 287 & 0.690 & $<0.001$ & 25.35 & \pm 0.57 & 0.0513 & \pm 0.0018 & 251 & \pm 6 & & \\
\hline 8.1 & m,hd,ov & 615 & 150 & 0.244 & 0.047 & 2.55 & \pm 0.08 & 0.1370 & \pm 0.0014 & 2131 & \pm 54 & $2189 \pm 18$ & 97 \\
\hline 9.1 & e,osc,ov & 104 & 92 & 0.878 & 0.002 & 5.40 & \pm 0.17 & 0.0759 & \pm 0.0065 & 1096 & \pm 32 & $1093 \pm 183$ & 100 \\
\hline 10.1 & $\mathrm{e}, \mathrm{osc}, \mathrm{p}$ & 285 & 172 & 0.601 & $<0.001$ & 17.66 & \pm 0.33 & 0.0511 & \pm 0.0022 & 358 & \pm 7 & & \\
\hline 10.2 & $\mathrm{e}, \mathrm{osc}, \mathrm{p}$ & 202 & 114 & 0.565 & $<0.001$ & 18.67 & \pm 0.39 & 0.0538 & \pm 0.0016 & 338 & \pm 7 & & \\
\hline 11.1 & $\mathrm{~m}, \mathrm{osc}, \mathrm{p}$ & 255 & 220 & 0.863 & $<0.001$ & 17.91 & \pm 0.53 & 0.0555 & \pm 0.0017 & 352 & \pm 10 & & \\
\hline 11.2 & $\mathrm{e}, \mathrm{osc}, \mathrm{p}$ & 198 & 119 & 0.600 & $<0.001$ & 17.82 & \pm 0.60 & 0.0520 & \pm 0.0021 & 355 & \pm 12 & & \\
\hline 12.1 & $\mathrm{r}, \mathrm{h}, \mathrm{p}$ & 802 & 2 & 0.002 & 0.028 & 10.99 & \pm 0.34 & 0.0594 & \pm 0.0006 & 561 & \pm 17 & & \\
\hline 12.2 & $\mathrm{r}, \mathrm{h}, \mathrm{p}$ & 719 & 2 & 0.003 & $<0.001$ & 10.83 & \pm 0.22 & 0.0580 & \pm 0.0011 & 570 & \pm 11 & & \\
\hline 13.2 & $\mathrm{~m}, \mathrm{sz}, \mathrm{ov}$ & 329 & 670 & 2.035 & 0.095 & 10.41 & \pm 0.29 & 0.0600 & \pm 0.0015 & 591 & \pm 16 & & \\
\hline 13.1 & $\mathrm{~m}, \mathrm{sz}, \mathrm{ov}$ & 451 & 1000 & 2.215 & 0.051 & 10.41 & \pm 0.29 & 0.0596 & \pm 0.0008 & 591 & \pm 16 & & \\
\hline 14.1 & $\mathrm{e}, \mathrm{osc}, \mathrm{p}, \mathrm{fr}$ & 168 & 102 & 0.604 & $<0.001$ & 18.08 & \pm 0.50 & 0.0525 & \pm 0.0016 & 350 & \pm 9 & & \\
\hline 14.2 & $\mathrm{~m}, \mathrm{osc}, \mathrm{p}, \mathrm{fr}$ & 303 & 257 & 0.845 & $<0.001$ & 17.84 & \pm 0.49 & 0.0526 & \pm 0.0012 & 354 & \pm 9 & & \\
\hline 15.1 & e,hd,ov & 1080 & 213 & 0.197 & 0.537 & 5.42 & \pm 0.24 & 0.0780 & \pm 0.0014 & 1091 & \pm 44 & $1147 \pm 35$ & 95 \\
\hline
\end{tabular}

Site grain type and analysis location: $\mathrm{p}=$ prism, $\mathrm{ov}=\mathrm{oval}$, $\mathrm{fr}=$ fragment, $\mathrm{e}=\mathrm{end}, \mathrm{m}=$ middle, $\mathrm{c}=\mathrm{core}, \mathrm{r}=$ rim/overgrowth

Site CL imagery: osc $=$ oscillatory zoned, $\mathrm{h}=$ homogeneous, $\mathrm{hd}=$ homogeneous dark, low luminescence, sz=sector $\mathrm{zoned}$, rex $=\mathrm{recrystallised}$

All analytical errors are given a $1 \sigma$

Concordance and ${ }^{207} \mathrm{~Pb} /{ }^{206} \mathrm{~Pb}$ ages only given for $>1000 \mathrm{Ma}$ old sites

f206\% is the amount of ${ }^{206} \mathrm{~Pb}$ modelled as non-radiogenic, based on measured ${ }^{204} \mathrm{~Pb}$ 


\begin{tabular}{|c|c|c|c|c|c|c|c|c|c|c|c|c|c|c|c|c|}
\hline analysis & site & age & $\mathrm{La}$ & $\mathrm{Ce}$ & $\operatorname{Pr}$ & $\mathrm{Nd}$ & $\mathrm{Sm}$ & $\mathrm{Eu}$ & Gd & $\mathrm{Tb}$ & Dy & Ho & Er & $\mathrm{Tm}$ & $\mathrm{Yb}$ & $\mathrm{Lu}$ \\
\hline \multicolumn{17}{|c|}{ zircons from 21-06 eclogite layer within blueschists: LA-ICP-MS in ANU } \\
\hline 1.1 & h,eq & 3035 & 1.50 & 44.1 & 3.41 & 28.4 & 28.8 & 12.2 & 100 & 40.3 & 477 & 143 & 607 & 131 & 1200 & 191 \\
\hline 2.2 & $\mathrm{e}, \mathrm{osc}, \mathrm{p}$ & 2795 & 0.03 & 14.3 & 0.08 & 1.31 & 2.81 & 0.18 & 17.6 & 5.72 & 73.2 & 26.6 & 122 & 26.8 & 244 & 42.2 \\
\hline 3.2 & $\mathrm{r}, \mathrm{osc}, \mathrm{p}$ & 415 & 0.02 & 11.5 & 0.08 & 1.15 & 3.39 & 0.64 & 19.8 & 6.86 & 89.1 & 33.7 & 163 & 36.1 & 346 & 63.3 \\
\hline 4.1 & e.osc,p & 256 & 0.03 & 7.65 & 0.07 & 1.12 & 2.60 & 0.31 & 18.3 & 6.57 & 88.6 & 34.4 & 164 & 37.1 & 347 & 61 \\
\hline 5.1 & r,hd,ov & 388 & 2.43 & 20.3 & 4.41 & 40.1 & 45.2 & 18.1 & 127 & 43.9 & 453 & 111 & 394 & 76.4 & 668 & 106 \\
\hline 6.1 & $\mathrm{~m}, \mathrm{osc}, \mathrm{p}$ & 505 & 0.06 & 4.04 & 0.07 & 1.03 & 2.04 & 0.35 & 13.4 & 4.37 & 58.3 & 21.6 & 101 & 22.2 & 209 & 37.0 \\
\hline 7.2 & $\mathrm{~m}, \mathrm{osc}, \mathrm{p}$ & 251 & 0.06 & 25.3 & 0.05 & 0.92 & 2.01 & 0.67 & 10.7 & 3.29 & 41.2 & 15.6 & 79.1 & 19.5 & 208 & 41.0 \\
\hline 8.1 & m,hd,ov & 2189 & 0.02 & 4.50 & 0.07 & 1.49 & 4.48 & 0.40 & 25.4 & 6.51 & 66.9 & 19.3 & 72.9 & 13.7 & 112 & 17.4 \\
\hline 8.B & e,hd,ov & 2189 & 0.01 & 4.46 & 0.06 & 1.39 & 3.99 & 0.38 & 20.9 & 5.49 & 54.0 & 15.1 & 56.6 & 10.3 & 85.1 & 13.0 \\
\hline 9.1 & e,osc,ov & 1093 & 0.14 & 11.7 & 0.10 & 1.12 & 2.25 & 0.52 & 12.3 & 4.18 & 56.7 & 21.2 & 101 & 21.9 & 207 & 36.7 \\
\hline 10.1 & $\mathrm{e}, \mathrm{osc}, \mathrm{p}$ & 358 & 0.04 & 14.6 & 0.07 & 1.06 & 1.91 & 0.68 & 9.49 & 3.34 & 43.1 & 16.8 & 88.3 & 20.8 & 216 & 47.2 \\
\hline 11.2 & e,osc,p & 355 & bdl & 7.76 & 0.08 & 1.37 & 3.10 & 0.65 & 17.2 & 5.35 & 69.4 & 25.4 & 122 & 27.2 & 258 & 47.2 \\
\hline 12.2 & $\mathrm{r}, \mathrm{h}, \mathrm{p}$ & 570 & 0.62 & 8.59 & 0.74 & 4.78 & 5.11 & 3.14 & 24.0 & 10.2 & 135 & 47.4 & 246 & 66.1 & 760 & 144 \\
\hline 14.1 & $\mathrm{e}, \mathrm{osc}, \mathrm{p}, \mathrm{fr}$ & 350 & 0.19 & 15.8 & 0.19 & 2.46 & 5.05 & 0.99 & 28.9 & 8.72 & 110 & 38.5 & 179 & 40.1 & 371 & 63.5 \\
\hline 15.1 & e,hd,ov & 1080 & 0.78 & 10.1 & 0.94 & 5.77 & 4.64 & 1.79 & 13.9 & 3.06 & 23.1 & 5.13 & 15.9 & 2.85 & 22.4 & 3.84 \\
\hline 15.2 & e,hd,ov & 1080 & 2.48 & 14.9 & 1.88 & 10.3 & 7.19 & 2.21 & 16.1 & 3.30 & 24.7 & 4.86 & 14.4 & 2.29 & 16.3 & 2.27 \\
\hline 16 & hd,fr & $1070 *$ & 10.3 & 127 & 14.0 & 101 & 103 & 39.4 & 245 & 72.1 & 673 & 162 & 587 & 114 & 945 & 146 \\
\hline \multicolumn{17}{|c|}{ zircons from RB-2 blueschist interlayered with eclogite: SHRIMP in Hiroshima University } \\
\hline 2.1 & r,h,pov & 594 & 0.03 & 18.9 & 0.02 & 1.22 & 2.73 & 0.44 & 13.6 & 4.57 & 53.2 & 19.5 & 82.4 & 19 & 185 & 36.2 \\
\hline 4.1 & $\mathrm{r}, \mathrm{h}, \mathrm{ov}$ & 596 & 0.02 & 5.11 & 0.03 & 4.79 & 12.5 & 0.15 & 48.1 & 11.5 & 92.2 & 25.0 & 85.3 & 17 & 145 & 24.0 \\
\hline 5.1 & $\mathrm{r}, \mathrm{h}, \mathrm{ov}$ & 519 & 0.01 & 15.8 & 0.02 & 1.13 & 2.76 & 0.41 & 14.9 & 5.71 & 70.7 & 27.6 & 125 & 30 & 296 & 53.9 \\
\hline 6.1 & $\mathrm{r}, \mathrm{sz}, \mathrm{ov}$ & 559 & 0.02 & 5.13 & 0.02 & 3.24 & 9.07 & 0.17 & 29.4 & 5.91 & 34.6 & 6.02 & 14.1 & 2.12 & 14.5 & 1.91 \\
\hline \multicolumn{17}{|c|}{ zircons from RB-3 retrogressed high-pressure block: SHIMP in Hiroshima University } \\
\hline 3.2 & $\mathrm{r}, \mathrm{sz}, \mathrm{ov}$ & 406 & 0.01 & 20.4 & 0.04 & 4.46 & 8.23 & 1.43 & 35.9 & 11.7 & 133.9 & 48.4 & 203 & 46 & 417 & 72.9 \\
\hline \multicolumn{17}{|c|}{ example of eclogite metamorphic zircon the Franklin metamorphics, Tasmania: SHRIMP in Hiroshima University } \\
\hline 2.2 & m,h,ov & 513 & 0.00 & 0.24 & 0.01 & 0.07 & 0.44 & 0.40 & 3.67 & 0.96 & 5.79 & 1.02 & 2.64 & 0.43 & 3.35 & 0.54 \\
\hline
\end{tabular}

garnet from eclogite 21-06: LA-ICP-MS in Macquarie University 


\begin{tabular}{|c|c|c|c|c|c|c|c|c|c|c|c|c|c|c|c|}
\hline $2106-1 \mathrm{~A}$ & fr & 0.004 & 0.003 & 0.004 & 0.026 & 0.047 & 0.043 & 0.290 & 0.063 & 0.370 & 0.049 & 0.110 & 0.012 & 0.070 & 0.009 \\
\hline 2106-1B & fr & 0.004 & 0.001 & 0.003 & 0.023 & 0.078 & 0.059 & 0.410 & 0.130 & 1.270 & 0.250 & 0.710 & 0.085 & 0.500 & 0.063 \\
\hline $2106-2$ & fr & $<0.00$ & 0.004 & 0.004 & 0.035 & 0.083 & 0.080 & 0.550 & 0.130 & 1.090 & 0.200 & 0.600 & 0.069 & 0.550 & 0.078 \\
\hline $2106-3$ & $\mathrm{fr}$ & 0.012 & 0.017 & 0.008 & 0.043 & 0.100 & 0.069 & 0.510 & 0.097 & 0.660 & 0.130 & 0.490 & 0.085 & 0.770 & 0.140 \\
\hline $2106-4$ & fr & 0.005 & 0.010 & 0.006 & 0.051 & 0.120 & 0.083 & 0.480 & 0.110 & 1.060 & 0.320 & 1.460 & 0.240 & 2.270 & 0.360 \\
\hline $2106-5$ & fr & 0.003 & 0.002 & 0.003 & 0.036 & 0.063 & 0.049 & 0.380 & 0.120 & 1.190 & 0.270 & 0.950 & 0.120 & 0.790 & 0.090 \\
\hline \multicolumn{16}{|c|}{ garnet from blueschist RB-2: LA-ICP-MS in Macquarie University } \\
\hline RB2-1A & fr & 0.002 & 0.003 & 0.003 & 0.027 & 0.059 & 0.047 & 0.360 & 0.110 & 0.990 & 0.230 & 0.740 & 0.110 & 0.810 & 0.120 \\
\hline RB2-1B & fr & 0.006 & 0.017 & 0.008 & 0.054 & 0.079 & 0.053 & 0.390 & 0.110 & 1.020 & 0.230 & 0.780 & 0.100 & 0.840 & 0.140 \\
\hline RB2-2 & fr & 0.004 & 0.006 & 0.004 & 0.036 & 0.074 & 0.059 & 0.490 & 0.160 & 1.540 & 0.430 & 1.610 & 0.230 & 1.990 & 0.310 \\
\hline RB2-3 & $\mathrm{fr}$ & 0.004 & $<0.00$ & 0.002 & 0.027 & 0.082 & 0.053 & 0.480 & 0.150 & 1.570 & 0.440 & 1.720 & 0.260 & 2.240 & 0.370 \\
\hline RB2-4 & fr & 0.005 & 0.004 & 0.004 & 0.030 & 0.085 & 0.069 & 0.450 & 0.140 & 1.130 & 0.220 & 0.630 & 0.079 & 0.530 & 0.067 \\
\hline
\end{tabular}

grain morphology: eq=equant, $\mathrm{p}=$ prismatic, $\mathrm{ov}=\mathrm{oval}, \mathrm{fr}=$ grain fragment, $\mathrm{e}=$ grain $\mathrm{end}, \mathrm{m}=$ grain middle, $\mathrm{r}=$ overgrowth, $\mathrm{c}=$ core

$\mathrm{CL}$ imagery: $\mathrm{osc}=$ oscillatory zoned, $\mathrm{sz}=$ sector zoned, $\mathrm{h}=$ homogeneous, $\mathrm{hd}=$ homogeneous dark, rex $=$ recrystallised

age is SHRIMP U-Pb age, apart from *=LA-ICP-MS approximate $\mathrm{U}-\mathrm{Pb}$ age 


\begin{tabular}{ccccc}
\hline analysis & $\mathrm{U}(\mathrm{ppm})$ & ${ }^{238} \mathrm{U} /{ }^{206} \mathrm{~Pb}$ & ${ }^{207} \mathrm{~Pb} /{ }^{206} \mathrm{~Pb}$ \\
\hline $\mathrm{R}-4$ & 0.20 & $3.322 \pm 0.282$ & $0.7322 \pm 0.0717$ \\
$\mathrm{R}-5$ & 0.26 & $2.368 \pm 0.208$ & $0.7532 \pm 0.0724$ \\
$\mathrm{R}-6$ & 0.07 & $1.176 \pm 0.053$ & $0.7760 \pm 0.0333$ \\
$\mathrm{R}-7$ & 0.02 & $1.203 \pm 0.126$ & $0.7709 \pm 0.0792$ \\
$\mathrm{R}-8$ & 0.13 & $1.491 \pm 0.109$ & $0.7878 \pm 0.0583$ \\
$\mathrm{R}-9$ & 0.51 & $1.496 \pm 0.047$ & $0.8118 \pm 0.0254$ \\
$\mathrm{R}-9$ & 0.02 & $1.505 \pm 0.118$ & $0.8020 \pm 0.0666$ \\
$\mathrm{R}-10$ & 1.65 & $3.260 \pm 0.106$ & $0.7566 \pm 0.0480$ \\
$\mathrm{R}-11$ & 0.47 & $1.532 \pm 0.066$ & $0.7223 \pm 0.0602$ \\
$\mathrm{R}-12$ & 0.09 & $0.536 \pm 0.027$ & $0.8912 \pm 0.0647$ \\
$\mathrm{R}-13$ & 0.07 & $1.173 \pm 0.049$ & $0.7166 \pm 0.0534$ \\
$\mathrm{R}-14$ & 0.27 & $0.385 \pm 0.034$ & $0.7224 \pm 0.1608$ \\
$\mathrm{~T}-1$ & 1.59 & $0.852 \pm 0.012$ & $0.7889 \pm 0.0100$ \\
$\mathrm{~T}-2$ & 2.05 & $1.029 \pm 0.016$ & $0.7893 \pm 0.0124$ \\
$\mathrm{~T}-3$ & 0.15 & $0.189 \pm 0.005$ & $0.8393 \pm 0.0134$ \\
$\mathrm{~T}-4$ & 0.43 & $0.260 \pm 0.005$ & $0.8462 \pm 0.0124$ \\
$\mathrm{~T}-5$ & 0.98 & $0.683 \pm 0.011$ & $0.7947 \pm 0.0118$ \\
$\mathrm{~T}-6$ & 0.70 & $0.373 \pm 0.006$ & $0.8143 \pm 0.0119$ \\
$\mathrm{~T}-7$ & 1.25 & $0.574 \pm 0.011$ & $0.8126 \pm 0.0149$ \\
$\mathrm{~T}-8$ & 0.90 & $0.545 \pm 0.009$ & $0.8151 \pm 0.0129$ \\
$\mathrm{~T}-09$ & 1.19 & $0.801 \pm 0.024$ & $0.7768 \pm 0.0650$ \\
$\mathrm{~T}-10$ & 1.54 & $0.964 \pm 0.036$ & $0.7636 \pm 0.0811$ \\
$\mathrm{~T}-11$ & 0.68 & $0.435 \pm 0.013$ & $0.7994 \pm 0.0724$ \\
$\mathrm{~T}-12$ & 0.71 & $0.487 \pm 0.021$ & $0.7724 \pm 0.0961$
\end{tabular}

$\mathrm{R}=$ rutile, $\mathrm{T}=$ titanite. Analytical errors given at $1 \sigma$ 